\title{
A large and ubiquitous source of atmospheric formic acid
}

\author{
D. B. Millet ${ }^{1}$, M. Baasandorj ${ }^{1}$, D. K. Farmer ${ }^{2}$, J. A. Thornton ${ }^{3}$, K. Baumann ${ }^{4}$, P. Brophy ${ }^{2}$, S. Chaliyakunnel ${ }^{1}$, \\ J. A. de Gouw ${ }^{5,6}$, M. Graus ${ }^{5,6, *}$, L. Hu ${ }^{1, * *}$, A. Koss ${ }^{5,6}$, B. H. Lee ${ }^{3}$, F. D. Lopez-Hilfiker ${ }^{3}$, J. A. Neuman ${ }^{5,6}$, F. Paulot ${ }^{7}$, \\ J. Peischl ${ }^{5,6}$, I. B. Pollack ${ }^{5,6, * * *}$, T. B. Ryerson ${ }^{5}$, C. Warneke ${ }^{5,6}$, B. J. Williams ${ }^{8}$, and J. Xu ${ }^{9}$ \\ ${ }^{1}$ Department of Soil, Water, and Climate, University of Minnesota, Minneapolis-Saint Paul, MN 55108, USA \\ ${ }^{2}$ Department of Chemistry, Colorado State University, Fort Collins, CO 80523, USA \\ ${ }^{3}$ Department of Atmospheric Sciences, University of Washington, Seattle, WA 98195, USA \\ ${ }^{4}$ Atmospheric Research \& Analysis Inc., Cary, NC 27513, USA \\ ${ }^{5}$ Chemical Sciences Division, NOAA Earth System Research Laboratory, Boulder, CO 80305, USA \\ ${ }^{6}$ Cooperative Institute for Research in Environmental Sciences, University of Colorado, Boulder, CO 80309, USA \\ ${ }^{7}$ NOAA Geophysical Fluid Dynamics Laboratory, Princeton, NJ 08540, USA \\ ${ }^{8}$ Department of Energy, Environmental, and Chemical Engineering, Washington University in St. Louis, St. Louis, \\ MO 63130, USA \\ ${ }^{9}$ Department of Physics and Atmospheric Science, Dalhousie University, Halifax, NS B3H 4R2, Canada \\ * now at: Institute of Meteorology and Geophysics, University of Innsbruck, 6020 Innsbruck, Austria \\ ** now at: School of Engineering and Applied Sciences, Harvard University, Cambridge, MA 02138, USA \\ ${ }^{* * * *}$ now at: Department of Atmospheric Science, Colorado State University, Fort Collins, CO 80523, USA
}

Correspondence to: D. B. Millet (dbm@umn.edu)

Received: 1 January 2015 - Published in Atmos. Chem. Phys. Discuss.: 18 February 2015

Revised: 30 April 2015 - Accepted: 15 May 2015 - Published: 9 June 2015

\begin{abstract}
Formic acid (HCOOH) is one of the most abundant acids in the atmosphere, with an important influence on precipitation chemistry and acidity. Here we employ a chemical transport model (GEOS-Chem CTM) to interpret recent airborne and ground-based measurements over the US Southeast in terms of the constraints they provide on $\mathrm{HCOOH}$ sources and sinks. Summertime boundary layer concentrations average several parts-per-billion, $2-3 \times$ larger than can be explained based on known production and loss pathways. This indicates one or more large missing $\mathrm{HCOOH}$ sources, and suggests either a key gap in current understanding of hydrocarbon oxidation or a large, unidentified, direct flux of $\mathrm{HCOOH}$. Model-measurement comparisons implicate biogenic sources (e.g., isoprene oxidation) as the predominant $\mathrm{HCOOH}$ source. Resolving the unexplained boundary layer concentrations based (i) solely on isoprene oxidation would require a $3 \times$ increase in the model $\mathrm{HCOOH}$ yield, or (ii) solely on direct $\mathrm{HCOOH}$ emissions would require approximately a $25 \times$ increase in its biogenic flux. However, neither of these can explain the high $\mathrm{HCOOH}$ amounts seen in anthropogenic air masses and in the free troposphere. The
\end{abstract}

overall indication is of a large biogenic source combined with ubiquitous chemical production of $\mathrm{HCOOH}$ across a range of precursors. Laboratory work is needed to better quantify the rates and mechanisms of carboxylic acid production from isoprene and other prevalent organics. Stabilized Criegee intermediates (SCIs) provide a large model source of $\mathrm{HCOOH}$, while acetaldehyde tautomerization accounts for $\sim 15 \%$ of the simulated global burden. Because carboxylic acids also react with SCIs and catalyze the reverse tautomerization reaction, $\mathrm{HCOOH}$ buffers against its own production by both of these pathways. Based on recent laboratory results, reaction between $\mathrm{CH}_{3} \mathrm{O}_{2}$ and $\mathrm{OH}$ could provide a major source of atmospheric $\mathrm{HCOOH}$; however, including this chemistry degrades the model simulation of $\mathrm{CH}_{3} \mathrm{OOH}$ and $\mathrm{NO}_{x}: \mathrm{CH}_{3} \mathrm{OOH}$. Developing better constraints on SCI and $\mathrm{RO}_{2}+\mathrm{OH}$ chemistry is a high priority for future work. The model neither captures the large diurnal amplitude in $\mathrm{HCOOH}$ seen in surface air, nor its inverted vertical gradient at night. This implies a substantial bias in our current representation of deposition as modulated by boundary layer dynamics, and may indicate an $\mathrm{HCOOH}$ sink underestimate and 
thus an even larger missing source. A more robust treatment of surface deposition is a key need for improving simulations of $\mathrm{HCOOH}$ and related trace gases, and our understanding of their budgets.

\section{Introduction}

Formic acid ( $\mathrm{HCOOH})$ is, along with acetic acid $\left(\mathrm{CH}_{3} \mathrm{COOH}\right)$, the dominant carboxylic acid in the troposphere. Both are major sources of atmospheric acidity, and together they can contribute $>60 \%$ of the free acidity in precipitation in remote areas and $>30 \%$ in more polluted regions (Andreae et al., 1988; Galloway et al., 1982; Keene et al., 1983; Keene and Galloway, 1984). $\mathrm{HCOOH}$ can also be a significant sink for in-cloud $\mathrm{OH}$ radical concentrations (Jacob, 1986), and is therefore key to atmospheric aqueous-phase chemistry through its effects on oxidant levels, $\mathrm{pH}$-dependent reaction rates, and solubilities. Recent work has shown that the atmospheric abundance of $\mathrm{HCOOH}$ is substantially larger than can be explained based on current understanding of its budget (Cady-Pereira et al., 2014; Le Breton et al., 2012; Paulot et al., 2011; Stavrakou et al., 2012), implying the existence of a large missing source, or a dramatic sink overestimate. Here, we employ a chemical transport model (GEOS-Chem CTM) to interpret a combination of recent airborne and ground-based measurements in terms of the constraints they provide on the atmospheric biogeochemistry of $\mathrm{HCOOH}$.

$\mathrm{HCOOH}$ is produced in the atmosphere during the photochemical oxidation of biogenic and anthropogenic volatile organic compounds (VOCs), and is emitted directly through a variety of processes. Photochemical production is thought to be the largest global source of $\mathrm{HCOOH}$, but the magnitude is highly uncertain. For instance, Paulot et al. (2009a) recently estimated the $\mathrm{HCOOH}$ yield from isoprene at $10 \%$ under $\mathrm{NO}_{x}$-dominated conditions, 5-10× higher than standard chemical mechanisms had implied. $\mathrm{HCOOH}$ is also emitted directly from vegetation in a light- and temperaturedependent manner (Kesselmeier et al., 1998; Kesselmeier and Staudt, 1999), although the flux is bi-directional, so that the net effect can be emission or uptake depending on the ambient concentration (Kesselmeier, 2001; Kuhn et al., 2002). Other emission sources include biomass and biofuel burning (e.g., Goode et al., 2000), soils (e.g., Sanhueza and Andreae, 1991), agriculture (e.g., Ngwabie et al., 2008), and fossil fuel combustion (e.g., Kawamura et al., 1985; Talbot et al., 1988). Radiocarbon studies in Europe have shown that atmospheric $\mathrm{HCOOH}$ is mainly composed of modern carbon, even in winter, which would suggest that the fossil fuel contribution (via emission of precursors or of $\mathrm{HCOOH}$ itself) is minor (Glasius et al., 2000, 2001).

Heterogeneous sources have also been proposed. For example, $\mathrm{HCOOH}$ can be rapidly produced in cloud water from the reaction of hydrated formaldehyde with $\mathrm{OH}_{(\mathrm{aq})}$ (Jacob,
1986; Lelieveld and Crutzen, 1991). However, formate itself is also rapidly oxidized by $\mathrm{OH}_{(\mathrm{aq})}$, and as a result evasion of $\mathrm{HCOOH}$ to the gas phase would only be expected for moderately acidic clouds $(\mathrm{pH}<5)$ (Jacob, 1986). In addition, $\mathrm{HCOOH}$ production has been observed during organic aerosol aging in the laboratory (Eliason et al., 2003; Molina et al., 2004; Pan et al., 2009; Park et al., 2006; Vlasenko et al., 2008; Walser et al., 2007), raising the question of whether this is also important in the ambient atmosphere (Paulot et al., 2011). With a continental organic aerosol source of approximately $150 \mathrm{TgC} \mathrm{yr}^{-1}$ globally (Heald et al., 2010), a large $\mathrm{HCOOH}$ yield from aerosol oxidation would be needed to have a major impact on its overall budget (given a recent top-

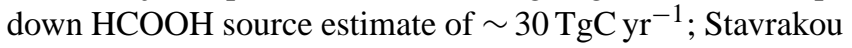
et al., 2012).

$\mathrm{HCOOH}$ is soluble in water, with an effective Henry's law constant of $\sim 10^{7} \mathrm{M} \mathrm{atm}^{-1}$ at $\mathrm{pH} 7$ (Sander, 2015), and is efficiently removed from the atmospheric boundary layer through wet and dry deposition. On the other hand, photochemical oxidation of $\mathrm{HCOOH}$ proceeds relatively slowly ( $\tau \sim 25$ days), so its effective lifetime in the free troposphere is considerably longer than it is in the boundary layer. Irreversible uptake on dust is another minor sink (e.g., Hatch et al., 2007; Paulot et al., 2011), and the overall atmospheric lifetime of $\mathrm{HCOOH}$ has been estimated at approximately 2-4 days (Chebbi and Carlier, 1996; Paulot et al., 2011; Stavrakou et al., 2012).

Recent advances in remote sensing (Cady-Pereira et al., 2014; Stavrakou et al., 2012; Zander et al., 2010) and in situ (Baasandorj et al., 2015; Le Breton et al., 2012; Liu et al., 2012; Veres et al., 2011; Yuan et al., 2015) measurement capabilities have led to the realization that atmospheric $\mathrm{HCOOH}$ concentrations are much too high to be consistent with present estimates of the source and sink magnitudes. In turn, this points to a key gap in present understanding of the atmospheric reactive carbon budget. A number of missing sources have been proposed to explain this discrepancy, related to vegetation (Le Breton et al., 2012; Paulot et al., 2011; Stavrakou et al., 2012), fires (Paulot et al., 2011; R'Honi et al., 2013), anthropogenic VOCs (Le Breton et al., 2012), and photooxidation of organic aerosols (Paulot et al., 2011). In this paper, we employ measurements from a suite of recent airborne and ground-based studies to shed light on this issue and derive a better understanding of atmospheric $\mathrm{HCOOH}$. These studies were carried out over the US Southeast during summer 2013 as part of the Southeast Nexus study (SENEX; http://www. esrl.noaa.gov/csd/projects/senex/), the Southern Oxidant and Aerosol Study (SOAS; http://soas2013.rutgers.edu/), and the St. Louis Air Quality Regional Study (SLAQRS; Baasandorj et al., 2015). Both SENEX and SOAS were part of the larger Southeast Atmosphere Study (SAS; http://www.eol.ucar.edu/ field_projects/sas). As we will show, the ensemble of observational constraints imply that (i) biogenic $\mathrm{HCOOH}$ sources are currently underestimated and predominate the $\mathrm{HCOOH}$ 
budget, and (ii) there is an undefined and widespread chemical source of $\mathrm{HCOOH}$ from a range of different precursor species.

\section{Simulation of atmospheric $\mathrm{HCOOH}$}

\subsection{Model overview}

We use the GEOS-Chem global 3-D CTM (http://www. geos-chem.org) to simulate $\mathrm{HCOOH}$ and related chemical species for 2013. The model runs employ meteorological data from the GEOS-5 Forward Processing (GEOS-FP) Atmospheric Data Assimilation System, which have a native resolution of $0.25^{\circ}$ latitude $\times 0.3125^{\circ}$ longitude and 72 vertical levels. For the present analysis we degrade the resolution to $2^{\circ} \times 2.5^{\circ}$ with 47 vertical levels and use a $15 \mathrm{~min}$ transport time step.

GEOS-Chem uses the TPCORE advection algorithm of Lin and Rood (1996), convective transport computed as described by $\mathrm{Wu}$ et al. (2007), and the non-local boundary layer mixing scheme of Lin and McElroy (2010). Wet deposition of $\mathrm{HCOOH}$ and other gases proceeds as described by Amos et al. (2012), and dry deposition is based on a standard resistance-in-series parameterization (Wang et al., 1998; Wesely, 1989). The chemical mechanism used here is as described elsewhere (Fischer et al., 2012; Mao et al., 2010, 2013a, b; Paulot et al., 2011), with a number of updates and modifications detailed below. Emissions relevant to the simulation of $\mathrm{HCOOH}$ are also described below. Further details on the GEOS-Chem model can be found at http: //www.geos-chem.org.

Figure 1 shows the global distribution of $\mathrm{HCOOH}$ sources in our base-case simulation. These include $51.0 \mathrm{Tg} \mathrm{yr}^{-1}$ from the photochemical oxidation of VOCs and $10.5 \mathrm{Tg} \mathrm{yr}^{-1}$ from direct emissions, and are computed as described next. Sinks include wet + dry deposition $\left(29.8 \mathrm{Tg} \mathrm{yr}^{-1}\right.$ wet; $20.8 \mathrm{Tg} \mathrm{yr}^{-1}$ dry), photochemical loss $\left(9.5 \mathrm{Tg} \mathrm{yr}^{-1}\right)$, and dust uptake (1.2 $\left.\mathrm{Tg} \mathrm{yr}^{-1}\right)$.

\subsection{Emissions}

Global anthropogenic emissions of $\mathrm{CO}, \mathrm{NO}_{x}$, and $\mathrm{SO}_{x}$ in GEOS-Chem use the Emissions Database for Global Atmospheric Research (EDGAR) 3.2-FT2000 inventory (Olivier et al., 2005), while anthropogenic VOC emissions are from the Reanalysis of the Tropospheric Chemical Composition (RETRO) inventory (Schultz et al., 2007) implemented as described by $\mathrm{Hu}$ et al. (2015a). Over North America, these inventories are overwritten by the US EPA's National Emissions Inventory (NEI) 2005 (www.epa.gov/ttnchie1/ net/2005inventory.html) and by Environment Canada's National Pollutant Release Inventory (NPRI) (www.ec.gc.ca/ inrp-npri/). Emissions from open and domestic biomass burning are based on the version 3 of the Global Fire Emissions Database (GFED3) for 2011 (van der Werf et al., 2010)

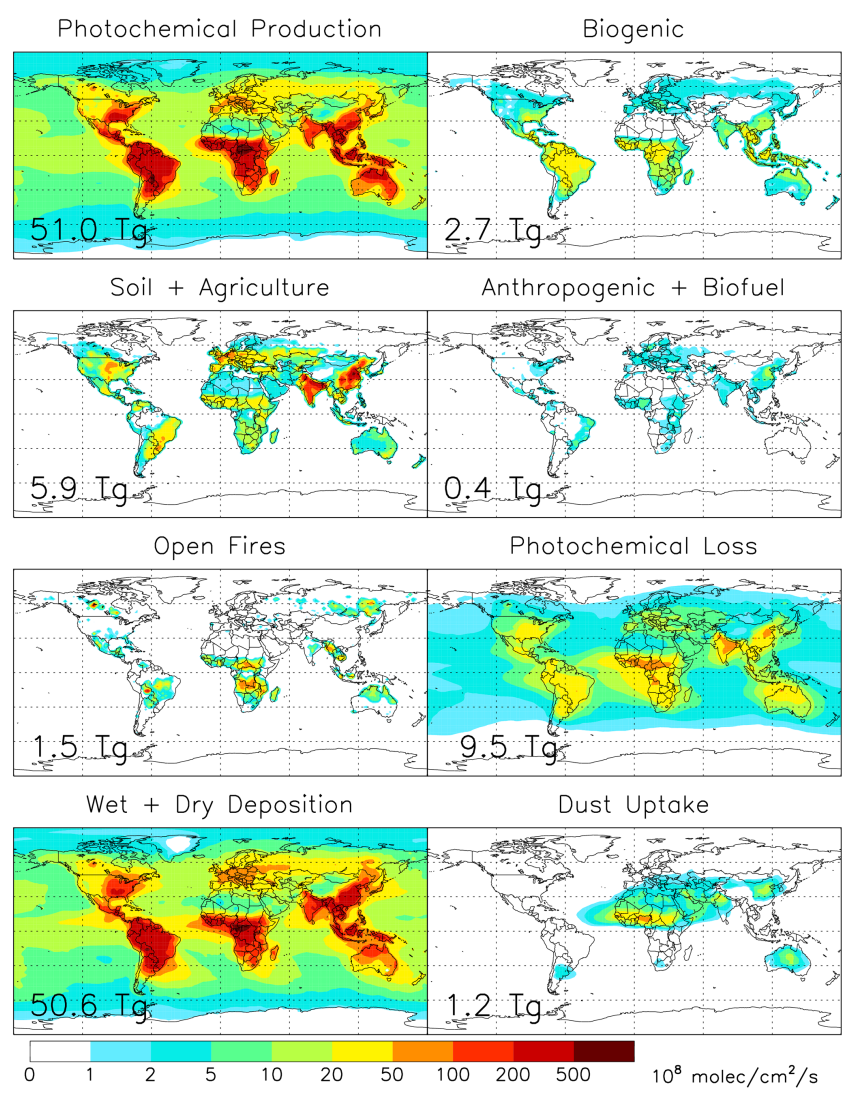

Figure 1. Global distribution of $\mathrm{HCOOH}$ sources in the GEOSChem base-case simulation. Note nonlinear color scale.

and on Yevich and Logan (2003), respectively. In all cases, $\mathrm{HCOOH}$ emissions are estimated by scaling those of $\mathrm{CO}$ to observed $\mathrm{HCOOH}$ : $\mathrm{CO}$ emission ratios, following Paulot et al. (2011). Because GFED3 is not available for 2013, individual fire plumes are removed from the model-measurement comparisons as described later.

Recent measurements in London, UK (Bannan et al., 2014), imply an anthropogenic $\mathrm{HCOOH}$ : $\mathrm{CO}$ emission ratio of $1.22 \times 10^{-3} \mathrm{~mol} \mathrm{~mol}^{-1}, 6 \times$ higher than the value used here based on Talbot et al. (1988). However, given a direct $\mathrm{CO}$ source from fossil fuels of $\sim 400 \mathrm{Tg} \mathrm{yr}^{-1}$ globally (Duncan et al., 2007), even this newly reported emission ratio would imply a corresponding $\mathrm{HCOOH}$ source of $<1 \mathrm{Tg} \mathrm{yr}^{-1}$. The direct anthropogenic $\mathrm{HCOOH}$ source is thus very small compared to the other sources shown in Fig. 1 .

Direct emissions of $\mathrm{HCOOH}$ and other VOCs (including isoprene and monoterpenes) from terrestrial vegetation are estimated using version 2.1 of the Model of Emissions of Gases and Aerosols from Nature (MEGANv2.1) (Guenther et al., 2012), implemented in GEOS-Chem as described by $\mathrm{Hu}$ et al. (2015b). Bottom-up biogenic VOC flux estimates can vary significantly depending on the land cover, meteorology, and forest canopy parameterization used to compute the 
emissions. Here we employ monthly mean leaf area indices derived from MODIS observations (Myneni et al., 2007; leaf area index (LAI) of year 2008 for all ensuing years), vegetation coverage for 15 plant functional types from version 4 of the Community Land Model (CLM4; Oleson et al., 2010), and the Parameterized Canopy Environment Emission Activity (PCEEA) algorithm described by Guenther et al. (2006). The version 2.1 of the Model of Emissions of Gases and Aerosols from Nature (MEGANv2.1) emissions are then derived using the same GEOS-FP meteorological fields that drive GEOS-Chem. $\mathrm{HCOOH}$ and other compounds undergoing bi-directional exchange are treated as described by Millet et al. (2010) and Guenther et al. (2012). Marine VOC emissions, along with direct $\mathrm{HCOOH}$ emissions from agriculture and soils, are treated as described previously (Paulot et al., 2011).

Figure 1 shows the resulting global distribution of direct $\mathrm{HCOOH}$ emissions from terrestrial vegetation $\left(2.7 \mathrm{Tg} \mathrm{yr}^{-1}\right)$, soils + agriculture $\left(5.9 \mathrm{Tg} \mathrm{yr}^{-1}\right)$, anthropogenic sources $\left(0.4 \mathrm{Tg} \mathrm{yr}^{-1}\right.$; includes domestic biofuel), and open fires $\left(1.5 \mathrm{Tg} \mathrm{yr}^{-1}\right)$.

\subsection{Photochemical production of $\mathrm{HCOOH}$}

\subsubsection{Ozonolysis of terminal alkenes}

A number of prevalent atmospheric VOCs contain a terminal alkene moiety, including ethene, propene, isoprene, MACR, MVK, and many of the monoterpenes (e.g., $\beta$-pinene, $d$ limonene, camphene, sabinene, $\beta$-ocimene, $\beta$-phellandrene, and myrcene). Ozonolysis of such compounds leads to an energy-rich $\left[\mathrm{CH}_{2} \mathrm{OO}\right]^{*}$ Criegee intermediate, along with a carbonyl compound. In the case of ethene (Atkinson et al., 2006):

$$
\mathrm{O}_{3}+\mathrm{C}_{2} \mathrm{H}_{4} \longrightarrow\left[\begin{array}{c}
\mathrm{O}^{-}-\mathrm{O} \\
\mathrm{O}_{2} \\
\mathrm{H}_{2} \mathrm{C}-\mathrm{CH}_{2}
\end{array}\right]^{*} \longrightarrow \mathrm{HCHO}+\left[\mathrm{CH}_{2} \mathrm{OO}\right]^{*} .
$$

The nascent energy-rich Criegee intermediate can then undergo prompt unimolecular decomposition, or collisional stabilization to yield a stabilized Criegee intermediate (SCI):

$$
\begin{aligned}
& {\left[\mathrm{CH}_{2} \mathrm{OO}\right]^{*} \longrightarrow \text { Products }} \\
& {\left[\mathrm{CH}_{2} \mathrm{OO}\right]^{*}+\mathrm{M} \longrightarrow \mathrm{CH}_{2} \mathrm{OO}+\mathrm{M} .}
\end{aligned}
$$

The lifetime of stabilized $\mathrm{CH}_{2} \mathrm{OO}$ is long enough that it can undergo bimolecular reactions with a range of atmospheric compounds (Hasson et al., 2001; Hatakeyama and Akimoto, 1994; Neeb et al., 1996, 1997; Newland et al., 2015; Stone et al., 2014; Su et al., 2014; Vereecken et al., 2012; Welz et al., 2012, 2014). In particular, the reaction with water vapor leads to hydroxymethyl hydroperoxide (HMHP) (Hasson et al., 2001; Neeb et al., 1996, 1997):

$$
\mathrm{CH}_{2} \mathrm{OO}+\mathrm{H}_{2} \mathrm{O} \longrightarrow \mathrm{HOCH}_{2} \mathrm{OOH} \text {. }
$$

which is known to decompose heterogeneously to $\mathrm{HCOOH}$ $+\mathrm{H}_{2} \mathrm{O}$ (Neeb et al., 1997; Orzechowska and Paulson, 2005). While it is uncertain how readily this occurs in the atmosphere (Lee et al., 1993; Sauer et al., 2001; Valverde-Canossa et al., 2006; Weinstein-Lloyd et al., 1998), photooxidation of HMHP is likely to produce $\mathrm{HCOOH}$ in high yield as well (Neeb et al., 1997; Paulot et al., 2011; Stavrakou et al., 2012). For this work we assume prompt conversion of $\mathrm{HMHP}$ to $\mathrm{HCOOH}$. This simplification may slightly overestimate $\mathrm{HCOOH}$ production from the $\mathrm{CH}_{2} \mathrm{OO} \mathrm{SCI}$, but an offsetting factor is that there are a number of atmospheric compounds containing terminal alkene groups that are not explicitly represented in the GEOS-Chem chemical scheme.

Estimates of the $\mathrm{CH}_{2} \mathrm{OO}+\mathrm{H}_{2} \mathrm{O}$ rate coefficient $\left(k_{\left.\mathrm{CH}_{2} \mathrm{OO}+\mathrm{H}_{2} \mathrm{O}\right)}\right)$ vary widely. Stone et al. (2014) inferred an upper limit of $9 \times 10^{-17} \mathrm{~cm}^{3} \mathrm{molec}^{-1} \mathrm{~s}^{-1}$, with a best estimate of $5.4 \times 10^{-18} \mathrm{~cm}^{3} \mathrm{molec}^{-1} \mathrm{~s}^{-1}$ based on relative rate considerations. On the other hand, Newland et al. (2015) derived a value for $k_{\mathrm{CH}_{2} \mathrm{OO}+\mathrm{H}_{2} \mathrm{O} \text { of }}$ $(1.3 \pm 0.4) \times 10^{-15} \mathrm{~cm}^{3} \mathrm{molec}^{-1} \mathrm{~s}^{-1}$. For the base-case sim-

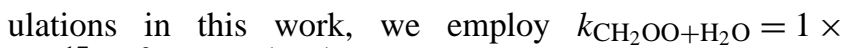
$10^{-17} \mathrm{~cm}^{3} \mathrm{molec}^{-1} \mathrm{~s}^{-1}$ following version 3.2 of the Master Chemical Mechanism (MCMv3.2) (Jenkin et al., 1997; Saunders et al., 2003). We also carry out separate sen-

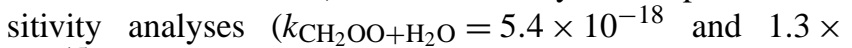
$10^{-15} \mathrm{~cm}^{3} \mathrm{molec}^{-1} \mathrm{~s}^{-1}$ ) to test how current uncertainty in this parameter affects our results. Reaction of $\mathrm{CH}_{2} \mathrm{OO}$ with the water dimer may also be significant in the atmosphere (Chao et al., 2015), and likewise leads to HMHP production (Ryzhkov and Ariya, 2003). However, we do not include such chemistry here, since (as will be seen) the above sensitivity runs already span conditions where $\mathrm{CH}_{2} \mathrm{OO}$ removal is dominated by reaction with water to form HMHP.

In addition to the sinks above, recent work has found that the $\mathrm{CH}_{2} \mathrm{OO}$ SCI can be lost by reaction with $\mathrm{HCOOH}$ and other carboxylic acids, and by self-reaction. Reactions between SCIs and carboxylic acids are treated as described later (Sect. 2.4). In the case of the $\mathrm{CH}_{2} \mathrm{OO}$ self-

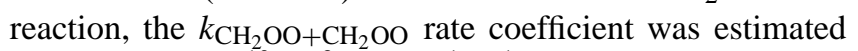
at $(4 \pm 2) \times 10^{-10} \mathrm{~cm}^{3} \mathrm{molec}^{-1} \mathrm{~s}^{-1}$ by $\mathrm{Su}$ et al. (2014), which is close to the gas kinetic collision value. However, subsequent work by the same group gives a lower value of $(8 \pm 4) \times 10^{-11} \mathrm{~cm}^{3} \mathrm{molec}^{-1} \mathrm{~s}^{-1}$ (Ting et al., 2014), which agrees with two other recent estimates of $(6 \pm 2) \times 10^{-11} \mathrm{~cm}^{3} \mathrm{molec}^{-1} \mathrm{~s}^{-1}$ (Buras et al., 2014) and $(7.4 \pm 0.6) \times 10^{-11} \mathrm{~cm}^{3}$ molec $^{-1} \mathrm{~s}^{-1}$ (Chhantyal-Pun et al., 2015). The base-case simulations presented here do not include the $\mathrm{CH}_{2} \mathrm{OO}$ self-reaction; rather, we include a separate sensitivity run based on the Ting et al. (2014) rate to 
assess the potential impact of this chemistry on atmospheric $\mathrm{HCOOH}$.

We employ here a stabilized $\mathrm{CH}_{2} \mathrm{OO}$ yield of 0.37 from ethene ozonolysis (Atkinson et al., 2006). Alam et al. (2011) reported a higher value of 0.54 , but more recent work by the same group gives a revised estimate of 0.37 (Newland et al., 2015), in agreement with the IUPAC recommendation. For propene, which is grouped with higher alkenes in the GEOS-Chem mechanism, we use an SCI yield of $12 \%$ for each of the two possible Criegee intermediates $\left(\mathrm{CH}_{2} \mathrm{OO}\right.$ and $\mathrm{CH}_{3} \mathrm{CHOO}$ ) based on MCMv3.2 (Jenkin et al., 1997; Saunders et al., 2003). Ozonolysis of isoprene, its oxidation products, and 2-methyl-3-buten-2-ol (MBO), and the associated SCI chemistry, is also implemented following MCMv3.2. Treatment of monoterpenes is described below.

\subsubsection{Alkyne oxidation}

Oxidation of acetylene (or other terminal alkyne) by $\mathrm{OH}$ leads to formic acid through formation of a peroxy radical that can then decompose to $\mathrm{HCOOH}$ plus an acyl radical, or to a dicarbonyl plus OH (Bohn et al., 1996; Hatakeyama et al., 1986):

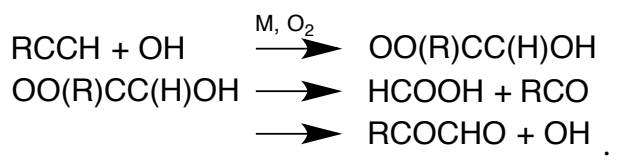

Paulot et al. (2011) found acetylene $\left(\mathrm{C}_{2} \mathrm{H}_{2}\right)$ to be the dominant non-biogenic precursor of formic acid in their simulations. We use in GEOS-Chem branching ratios of 0.364 and 0.636 for the acid and dicarbonyl channels, respectively, in acetylene oxidation (Bohn et al., 1996; Hatakeyama et al., 1986; Jenkin et al., 1997; Saunders et al., 2003).

\subsubsection{Isoprene oxidation by $\mathrm{OH}$}

The $\mathrm{HCOOH}$ yield from $\mathrm{OH}$-initiated isoprene oxidation is uncertain. The $\mathrm{OH}$-isoprene oxidation scheme employed here is based on the work of Paulot et al. (2009a, b; 2011), updated to account for peroxy radical isomerization reactions (Crounse et al., 2011, 2012). Pathways leading to $\mathrm{HCOOH}$ in this mechanism (aside from the ozonolysis reactions) include photooxidation of glycoaldehyde and hydroxyacetone (Butkovskaya et al., 2006a, b), degradation of isoprene nitrates (Paulot et al., 2009a), and oxidation of isoprene epoxides (Paulot et al., 2009b).

Figure S1 in the Supplement shows the resulting production rate of $\mathrm{HCOOH}$ over North America in GEOS-Chem. The total source from isoprene (including ozonolysis plus $\mathrm{OH}$ chemistry) over this domain corresponds to an average molar yield of $13 \%$ (2.6\% on a per-carbon basis), and accounts for nearly half of the overall photochemical $\mathrm{HCOOH}$ source in the model. Globally, isoprene oxidation accounts for $\sim 45 \%$ of the total HCOOH burden in the GEOS-Chem base-case simulation.

Evidence for direct $\mathrm{HCOOH}$ production from glycoaldehyde and hydroxyacetone as reported by Butkovskaya et al. (2006a, b) (and implemented here) is mixed. Orlando et al. (2012) did not find evidence for any significant $\mathrm{HCOOH}$ production from these compounds within the range of atmospherically relevant $\mathrm{NO}_{x}$ concentrations. Earlier work by Jenkin et al. (1993) on the Cl-atom-initiated oxidation of hydroxyacetone attributed the observed $\mathrm{HCOOH}$ production to secondary chemistry that would only be relevant to chamber conditions. Excluding the $\mathrm{HCOOH}$ source from glycoaldehyde and hydroxyacetone in the model reduces the global photochemical $\mathrm{HCOOH}$ source by over one-third, and (as will be seen) substantially increases the magnitude of the implied missing source.

\subsubsection{Monoterpene oxidation}

$\mathrm{HCOOH}$ can be produced during $\mathrm{OH}$-initiated oxidation and ozonolysis of monoterpenes (Larsen et al., 2001; Lee et al., 2006a, b; Orlando et al., 2000). The corresponding mechanisms and yields are not well quantified, and the overall effect on atmospheric $\mathrm{HCOOH}$ will vary with the mixture of monoterpenes at hand. For the simulations here we employ a single lumped monoterpenes species, with molar $\mathrm{HCOOH}$ yields of $15.5 \%$ (OH chemistry) and $7.5 \%$ (ozonolysis) (Paulot et al., 2011). This results in an $\mathrm{HCOOH}$ source of $9.8 \mathrm{Gmol}$ over the domain of Fig. S1, $18 \%$ of the model source from isoprene. Globally, monoterpenes account for $\sim 4 \%$ of the $\mathrm{HCOOH}$ burden in the base-case simulation.

\subsubsection{Keto-enol tautomerization}

Andrews et al. (2012) studied the photolysis of C-1 deuterated acetaldehyde $\left(\mathrm{CH}_{3} \mathrm{CDO}\right)$, and observed formation of its isomer $\mathrm{CH}_{2} \mathrm{DCHO}$. Modeling of the photo-isomerization implied that upon absorbing a photon, the initially excited acetaldehyde undergoes keto-enol tautomerization (as shown here for the non-deuterated molecule):

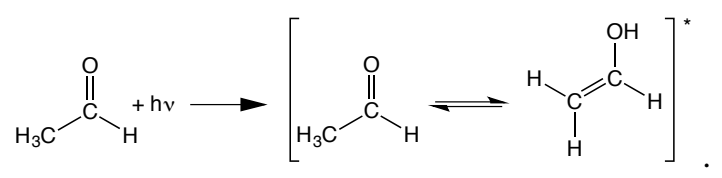

This in turn suggested that a fraction of the enol could be collisionally deactivated to form stable vinyl alcohol. Their best estimate for the vinyl alcohol quantum yield $\left(\phi_{\text {enol }}\right)$ was $21 \pm 4 \%$. Subsequent work (Clubb et al., 2012) observationally confirmed the formation of vinyl alcohol during acetaldehyde irradiation.

As the photooxidation of vinyl alcohol can lead to formic acid (Archibald et al., 2007; So et al., 2014), we include acetaldehyde tautomerization in GEOS-Chem to gauge its po- 
tential importance for atmospheric $\mathrm{HCOOH}$. There are likely to be two offsetting pressure effects on $\phi_{\text {enol }}$ : (i) competition between the photo-tautomerization reaction and collisional deactivation of the initially excited acetaldehyde molecule, and (ii) competition between collisional stabilization of the enol and dissociation. Since we lack quantitative constraints on either, we assume here a $21 \%$ quantum yield for enol production, with no pressure (or temperature) dependence. The subsequent photochemical oxidation of vinyl alcohol is then described according to the theoretical rate coefficients derived by So et al. (2014).

However, theory also suggests that $\mathrm{HCOOH}$ and other carboxylic acids (as well as other species) can effectively catalyze the reverse tautomerization of vinyl alcohol back to acetaldehyde (da Silva, 2010; Karton, 2014). Including the photo-tautomerization of acetaldehyde as well as the acidcatalyzed reverse reaction (applying the rate derived by da Silva (2010) for both formic and acetic acids), we find that the vinyl alcohol pathway accounts for $15 \%$ of the global $\mathrm{HCOOH}$ burden in the model.

As shown in Fig. S2, a consequence of this chemistry is that the efficiency of acetaldehyde tautomerization as a source of atmospheric $\mathrm{HCOOH}$ is inversely related to the abundance of $\mathrm{HCOOH}$ itself. $\mathrm{HCOOH}$ therefore buffers its own production by this mechanism; keto-enol tautomerization can provide a major fraction of the secondary $\mathrm{HCOOH}$ source when $\mathrm{HCOOH}$ concentrations are low, but it becomes negligible at higher levels of $\mathrm{HCOOH}$.

\subsection{6 $\mathrm{CH}_{3} \mathrm{O}_{2}+\mathrm{OH}$}

The rate coefficient for the $\mathrm{CH}_{3} \mathrm{O}_{2}+\mathrm{OH}$ reaction was recently measured at $(2.8 \pm 1.4) \times 10^{-10} \mathrm{~cm}^{3} \mathrm{molec}^{-1} \mathrm{~s}^{-1}$ (Bossolasco et al., 2014), based on the $\mathrm{CH}_{3} \mathrm{O}_{2}$ absorption cross section reported by Faragó et al. (2013). While the 2$3 \times$ uncertainty in that cross section (Atkinson and Spillman, 2002; Faragó et al., 2013; Pushkarsky et al., 2000) propagates onto the derived $\mathrm{CH}_{3} \mathrm{O}_{2}+\mathrm{OH}$ rate, the value derived by Bossolasco et al. (2014) is large enough that $\mathrm{OH}$ would represent an important $\mathrm{CH}_{3} \mathrm{O}_{2}$ sink in low-NO environments (Fittschen et al., 2014).

The potential implications of this chemistry for $\mathrm{HCOOH}$ and other species hinge on the reaction products, which are not known. Archibald et al. (2009) proposed three possible reaction paths $-\mathrm{H}$-atom abstraction to yield a Criegee intermediate, O-atom transfer to yield an alkoxy radical, and nucleophilic substitution to yield an alcohol:

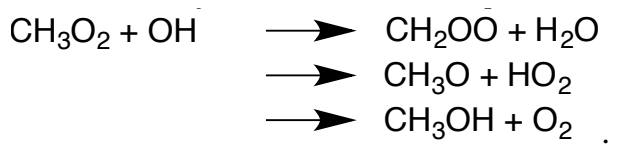

In the first case, $\mathrm{CH}_{2} \mathrm{OO}$ can go on to produce $\mathrm{HCOOH}$ as discussed earlier.
To test the possible importance of this chemistry for atmospheric $\mathrm{HCOOH}$, we carried out a sensitivity simulation using the reported $\mathrm{CH}_{3} \mathrm{O}_{2}+\mathrm{OH}$ rate coefficient (Bossolasco et al., 2014) and assuming that the reaction takes place exclusively via $\mathrm{H}$-atom abstraction. The resultant $\mathrm{CI}$ is then treated in the same way as in the case of ethene ozonolysis.

\subsection{Sinks of $\mathrm{HCOOH}$}

Wet and dry deposition are the predominant sinks for $\mathrm{HCOOH}$ in the model, and these are computed as described earlier. Photochemical oxidation of $\mathrm{HCOOH}$ by $\mathrm{OH}$ is treated using the current IUPAC recommendation of $k_{\mathrm{OH}+\mathrm{HCOOH}}=4.5 \times 10^{-13} \mathrm{~cm}^{3} \mathrm{molec}^{-1} \mathrm{~s}^{-1}$ (Atkinson et al., 2006).

While the $\mathrm{CH}_{2} \mathrm{OO}$ SCI can be a source of $\mathrm{HCOOH}$, recent work by Welz et al. (2014) suggests that SCIs in general can also provide a sink of $\mathrm{HCOOH}$ and other carboxylic acids, with $\mathrm{SCI}+\mathrm{RCOOH}$ rate coefficients in excess of $10^{-10} \mathrm{~cm}^{3} \mathrm{molec}^{-1} \mathrm{~s}^{-1}$ (i.e., approaching the collision limit). The reaction of $\mathrm{CH}_{2} \mathrm{OO}$ with $\mathrm{HCOOH}$ occurs in competition with the $\mathrm{CH}_{2} \mathrm{OO}+\mathrm{H}_{2} \mathrm{O}$ reaction that leads to $\mathrm{HCOOH}$ production. As with the acetaldehyde-vinyl alcohol system, $\mathrm{HCOOH}$ can thus be seen as buffering against its own production from $\mathrm{CH}_{2} \mathrm{OO}$. We performed a separate sensitivity simulation to evaluate the potential role of this chemistry for the atmospheric $\mathrm{HCOOH}$ budget, with results described in Sect. 4.

\section{Atmospheric observations of $\mathrm{HCOOH}$ and related species}

Here, we compare model results with recent airborne and ground-based measurements over North America to derive a better understanding of the $\mathrm{HCOOH}$ budget and potential missing sources. Measurements include the SENEX aircraft campaign (http://www.esrl.noaa.gov/csd/projects/senex/) over the US Southeast, the SOAS study (http://soas2013.rutgers.edu/) at the Southeastern Aerosol Research and Characterization (SEARCH) (http://www.atmospheric-research.com/studies/ SEARCH/index.html) Centreville site near Brent, Alabama, and the SLAQRS study (Baasandorj et al., 2015) in Greater Saint Louis, MO-IL. Flight tracks and site locations are shown in Fig. 2.

$\mathrm{HCOOH}$ was measured by chemical ionization mass spectrometry during each of the above campaigns, with analytical details as described by Brophy and Farmer (2015) for SOAS and Baasandorj et al. (2015) for SLAQRS. Two groups measured $\mathrm{HCOOH}$ on-board the WP-3D aircraft during SENEX: the University of Washington, with details described by Lee et al. (2014), and NOAA CSD as described by Neuman et al. $(2002,2010)$. For 1 min average data over the campaign, the two data sets agree with $R=0.90$, a major axis slope of 


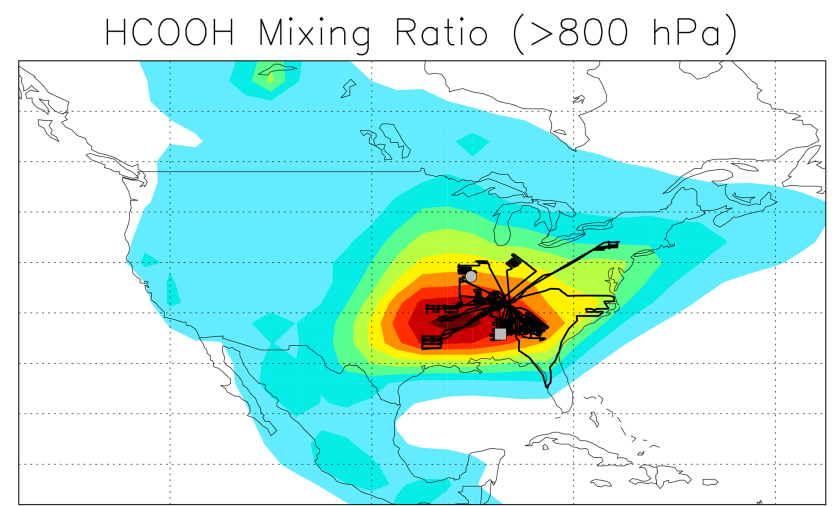

$\begin{array}{lllllllllll}0 & 130 & 260 & 390 & 520 & 650 & 780 & 910 & 1040 & 1170 & \text { [ppt] }\end{array}$

Figure 2. $\mathrm{HCOOH}$ mixing ratios in the summertime boundary layer as simulated by GEOS-Chem. Plotted is the June-September mean for $P>800 \mathrm{hPa}$. Also shown are the SENEX flight tracks (in black) and the SOAS and SLAQRS ground site locations (grey square and circle, respectively).

0.89 (NOAA vs. UW), and a mean relative error of $11 \%$. We use here the University of Washington data set, but the conclusions are not significantly altered if the NOAA CSD data set is used instead.

Additional chemical measurements shown below for SENEX include VOCs by proton transfer reaction-mass spectrometry (de Gouw and Warneke, 2007), CO by vacuum ultraviolet resonance fluorescence (Holloway et al., 2000), HCHO by laser-induced fluorescence (Cazorla et al., 2015; DiGangi et al., 2011; Hottle et al., 2009; Kaiser et al., 2014) as well as $\mathrm{NO}$ and $\mathrm{NO}_{2}$ by chemiluminescence (Pollack et al., 2010; Ryerson et al., 2000). Additional measurements shown for SLAQRS include VOCs by proton transfer reaction-mass spectrometry (Baasandorj et al., 2015; Hu et al., 2011), and CO by gas chromatography with a reducing compound photometer (Kim et al., 2013).

During SOAS, VOCs were measured by gas chromatography-mass spectrometry (Gilman et al., 2010), while $\mathrm{NO}_{2}$ was measured by photolytic conversion to $\mathrm{NO}$ with subsequent detection via chemiluminescence in excess ozone (CLD). The limit of detection (LOD) for $\mathrm{NO}_{2}$ during SOAS was $0.1 \mathrm{ppb}$, while precision was $\pm 4 \%$ at an overall propagated uncertainty of $\pm 15 \% . \mathrm{O}_{3}$ measurements during SOAS employed a pressure and temperature compensated UV absorption instrument (TEI-49i; Thermo Scientific, Franklin, MA 02038, USA), with absolute calibration based on the known absorption coefficient for $\mathrm{O}_{3}$ at $254 \mathrm{~nm}$. The LOD for $\mathrm{O}_{3}$ during SOAS was $1.2 \mathrm{ppb}$, precision was $\pm 3 \%$, and overall uncertainty was $\pm 6 \%$. $\mathrm{HNO}_{3}$ was determined by difference during SOAS, with one instrument channel measuring $\mathrm{NO}$ via CLD (as for $\mathrm{NO}_{2}$ above) downstream of a $350{ }^{\circ} \mathrm{C}$ Mo converter that quantitatively reduces ambient $\mathrm{HNO}_{3}$ to $\mathrm{NO}$, and the other channel measuring $\mathrm{NO}$ downstream of a $\mathrm{Na}_{2} \mathrm{CO}_{3}$-coated ( $1 \%$ in deionized water) denuder that removes nearly $100 \%$ of ambient $\mathrm{HNO}_{3}$. The channels switch every $10 \mathrm{~s}$. During SOAS, the LOD for $\mathrm{HNO}_{3}$ was 60 pptv, precision was $\pm 14 \%$, and the overall uncertainty was $\pm 17 \%$. SOAS also included mixing height measurements via lidar (CHM 15k Nimbus ceilometer; Jenoptik AG, 07743 Jena, Germany). The measurement is based on photon counting of back-scattered pulses of near-IR light (1064 $\mathrm{nm})$, and we assume here that the aerosol layer detected closest to the ground represents the mixing height. The measurement precision was $\pm 4 \%$ at an overall uncertainty of $\pm 13 \%$.

\subsection{Distribution of $\mathrm{HCOOH}$ over North America}

\subsubsection{Vertical profiles of $\mathrm{HCOOH}$ and related species}

Figure 3 shows average vertical profiles of $\mathrm{HCOOH}$ and an ensemble of related chemical species as measured over the US Southeast during SENEX. HCOOH mixing ratios average $\sim 2.5 \mathrm{ppb}$ near the surface, decreasing to $0.25-0.7 \mathrm{ppb}$ in the free troposphere. The measured concentrations approach those of HCHO (mean of $\sim 4 \mathrm{ppb}$ near the surface), which is a ubiquitous oxidation product of isoprene and many other VOCs. The high observed $\mathrm{HCOOH}$ concentrations indicate that this compound is a major component of the reactive carbon budget, and (if secondary in origin) a central product of VOC oxidation in the atmosphere.

Also shown in Fig. 3 are predicted concentrations from the GEOS-Chem base-case simulation described above. Here and elsewhere, the model has been sampled along the aircraft flight track at the time of measurement. We see that the mean vertical profiles of $\mathrm{CO}$, isoprene, the sum of methyl vinyl ketone and methacrolein (MVK+MACR; both are isoprene oxidation products), formaldehyde (HCHO), total monoterpenes $\left(\Sigma\right.$ MONOT), and $\mathrm{NO}_{x}$ are all well captured by the model. GEOS-Chem underpredicts $\mathrm{CO}$ in the free troposphere, consistent with a low model bias in the CO background (Kim et al., 2013), but otherwise the vertical profiles are in good agreement with observations, in terms of both magnitude and shape.

Conversely, simulated concentrations of $\mathrm{HCOOH}$ are dramatically low relative to the aircraft data, averaging only $\sim 1 \mathrm{ppb}$ near the surface. A similar issue is apparent for $\mathrm{CH}_{3} \mathrm{COOH}$. In addition to the boundary layer bias, we see for both acids a major model underestimate in the free troposphere: above $600 \mathrm{hPa}$, observed concentrations for both species average $0.25 \mathrm{ppb}$ or more, whereas those in the model are a factor of 10 less at $10-40$ ppt.

The comparisons shown in Fig. 3 do not provide any indication of a major bias in the simulated emissions of isoprene, monoterpenes, or other $\mathrm{HCHO}$ precursors that could come close to explaining the observed discrepancy for $\mathrm{HCOOH}$ and $\mathrm{CH}_{3} \mathrm{COOH}$. Likewise, overly vigorous boundary layer ventilation is untenable as an explanation, 

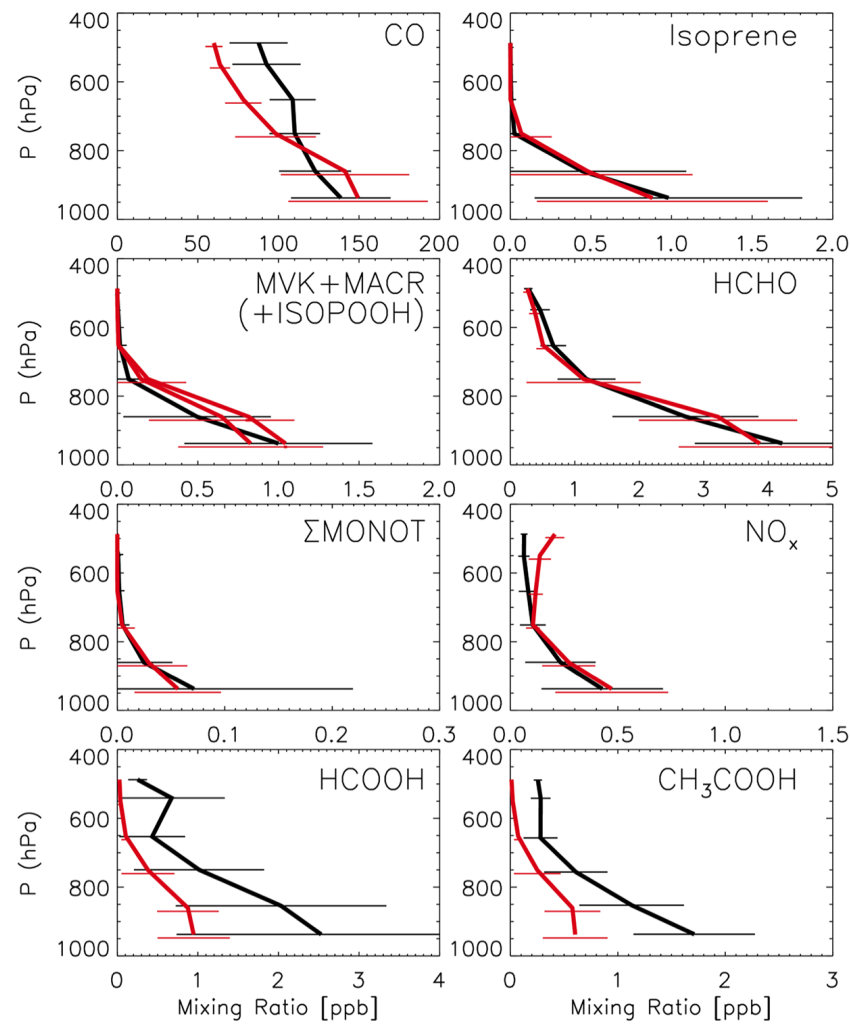

Figure 3. Vertical profiles of $\mathrm{HCOOH}$ and related species during summer over the US Southeast. Measurements from the SENEX campaign are plotted in black, and are compared to simulated concentrations from GEOS-Chem (in red) sampled along the flight track at the time of measurement. Horizontal lines show the standard deviation of concentration in each altitude bin. Fresh biomass burning $\left(\mathrm{CH}_{3} \mathrm{CN}>225 \mathrm{ppt}\right)$ and pollution $\left(\mathrm{NO}_{x} / \mathrm{NO}_{y}>0.4\right.$ or $\mathrm{NO}_{2}>4 \mathrm{ppb}$ ) plumes have been removed prior to plotting. Separate lines are shown for the simulated abundance of MVK+MACR and MVK+MACR plus isoprene hydroxyhydroperoxides (a.k.a. ISOPOOH), which can interfere with MVK+MACR measurements (Liu et al., 2013).

based on the accurate model profile shapes for the non-acid species, as well as the fact that both acids are biased low in the model throughout the vertical column. The aircraft measurements clearly demonstrate that some aspect of the model $\mathrm{HCOOH}$ budget is seriously in error, and this supports other recent studies based on satellite and in situ measurements (Cady-Pereira et al., 2014; Paulot et al., 2011; Stavrakou et al., 2012). Since the sources of $\mathrm{HCOOH}$ are thought to be mainly secondary in nature, this points to a significant gap in our current understanding of hydrocarbon oxidation chemistry. In the next section we apply tracertracer relationships measured and simulated during SENEX to shed light on potential missing terms in the $\mathrm{HCOOH}$ budget.

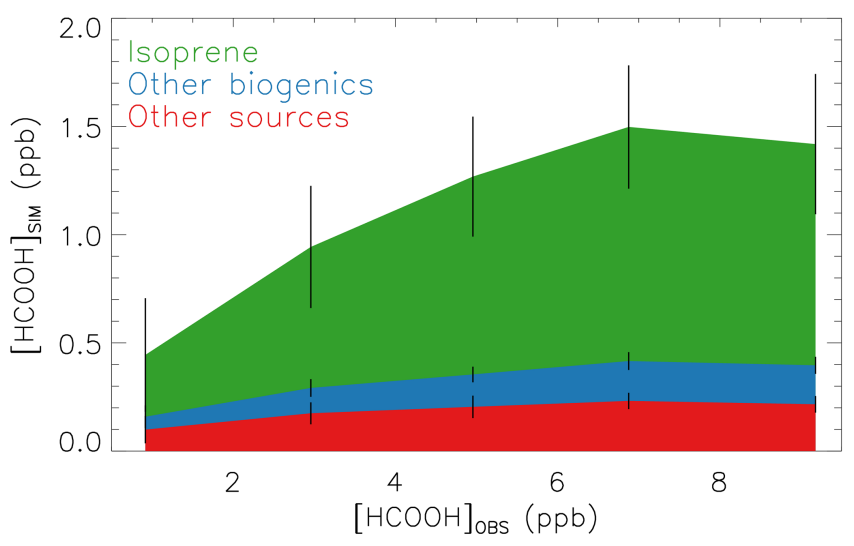

Figure 4. Simulated $\mathrm{HCOOH}$ binned and plotted as a function of the observed concentrations during the SENEX campaign over the US Southeast. Simulated values are shown as a stack plot, with $\mathrm{HCOOH}$ from the oxidation of isoprene (green), other biogenics (blue), and other sources (red) adding to give the total model amount. Vertical lines show the standard deviation of the simulated abundance in each bin.

\subsubsection{Relationship between $\mathrm{HCOOH}$ and other chemical tracers}

Figure 4 shows the simulated $\mathrm{HCOOH}$ mixing ratios during SENEX from (i) isoprene oxidation, (ii) other exclusively biogenic sources, and (iii) all other sources, binned and plotted as a function of the observed $\mathrm{HCOOH}$ amount. "Other sources" include photochemical production of $\mathrm{HCOOH}$ from primary VOCs with anthropogenic or mixed origins (e.g., ethene) as well as direct $\mathrm{HCOOH}$ emissions from nonbiogenic sources. We see in the figure that when the measured $\mathrm{HCOOH}$ concentrations are high, isoprene oxidation is the predominant model source. By itself, this is not clear evidence that the high observed $\mathrm{HCOOH}$ concentrations arise from isoprene oxidation, since the modeled $\mathrm{HCOOH}$ from isoprene is strongly correlated with that from other biogenic sources $(R=0.92)$. On the other hand, the sole secondary $\mathrm{HCOOH}$ source in the model that is purely anthropogenic (acetylene oxidation) has only a weak correlation $(R=0.29)$ with the $\mathrm{HCOOH}$ observations.

The strongest correlation between $\mathrm{HCOOH}$ and the extensive array of other chemicals observed during SENEX, aside from other carboxylic acids, is with methanol, with $R=0.70$ for the entire data set and $R=0.68$ within the planetary boundary layer (PBL; $P>800 \mathrm{hPa}$ ). An independent analysis (de Gouw et al., 2014) concluded that methanol variability during SENEX was dominated by emissions from the terrestrial biosphere, and this is consistent with findings from other studies (Hu et al., 2011; Millet et al., 2008b; Stavrakou et al., 2011; Wells et al., 2012, 2014). The observed HCOOHmethanol relationship thus provides an additional indication that biogenic sources are driving the abundance of atmospheric $\mathrm{HCOOH}$ over this region. 


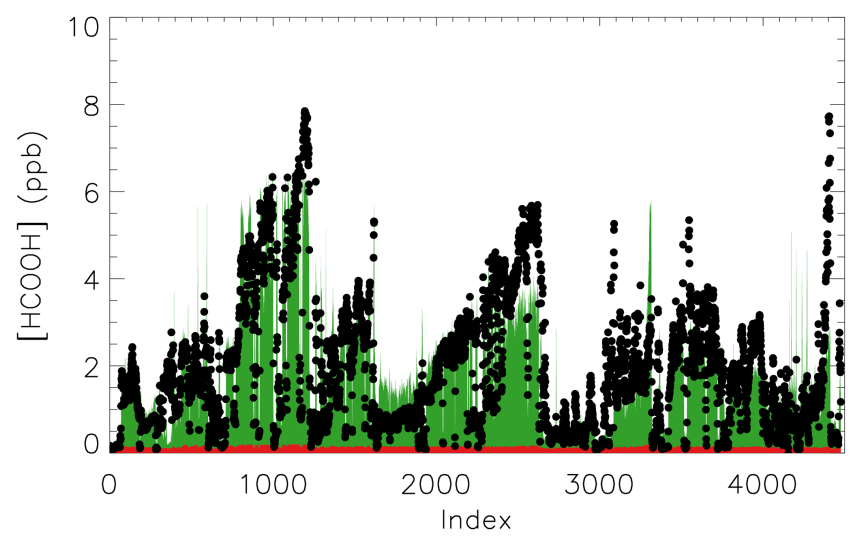

Figure 5. Source partitioning of atmospheric $\mathrm{HCOOH}$ based on a regression against methanol (as a biogenic tracer) and MEK (as a predominantly anthropogenic tracer) during the SENEX aircraft campaign. The figure shows the resulting attribution of the measured $\mathrm{HCOOH}$ abundance (black) to biogenic (green) and other (anthropogenic + background; red) sources.

Figure 5 shows a source attribution of atmospheric $\mathrm{HCOOH}$ based on multiple regression of the SENEX observations against concurrent measurements of methanol (as a biogenic tracer) and methyl ethyl ketone (MEK; as an anthropogenic tracer), and with the intercept set to the lowest $\mathrm{HCOOH}$ concentrations observed during the campaign (0.01 quantile; $0.1 \mathrm{ppb})$. MEK exhibits the strongest correlation with $\mathrm{HCOOH}$ of any anthropogenic tracer $(R=0.42$ within the PBL). While MEK is known to have some biogenic sources (de Gouw et al., 1999; Jordan et al., 2009; Kirstine et al., 1998; McKinney et al., 2011), it is thought to be mainly produced from the oxidation of butane and other anthropogenic hydrocarbons (Jenkin et al., 1997; Saunders et al., 2003). As we will see later, observations during SLAQRS in Greater St. Louis imply a significant anthropogenic contribution to atmospheric MEK in that location. We use it here as an anthropogenic tracer; to the degree that MEK is affected by biogenic sources, the associated anthropogenic $\mathrm{HCOOH}$ source fraction may be overstated.

We see in Fig. 5 that the resulting regression captures $74 \%$ of the variance in atmospheric $\mathrm{HCOOH}$, and on average attributes $86 \%$ of the observed $\mathrm{HCOOH}$ abundance to biogenic sources and less than $15 \%$ to other sources. A bootstrap analysis gives $95 \%$ uncertainty ranges of $82-90 \%$ and $10-18 \%$ for the mean biogenic and other contributions, respectively, while the variance inflation factor $(\mathrm{VIF}<5)$ shows that the regression is not unduly affected by multicollinearity. Here we have transformed (squared) the methanol concentrations to give a linear relationship with $\mathrm{HCOOH}$, using instead the untransformed data yields a smaller biogenic fraction (69\%) but a slightly degraded fit.

The above considerations point to biogenic VOC oxidation (or conceivably direct biotic emissions) as the largest source of atmospheric $\mathrm{HCOOH}$ over this part of North Amer-
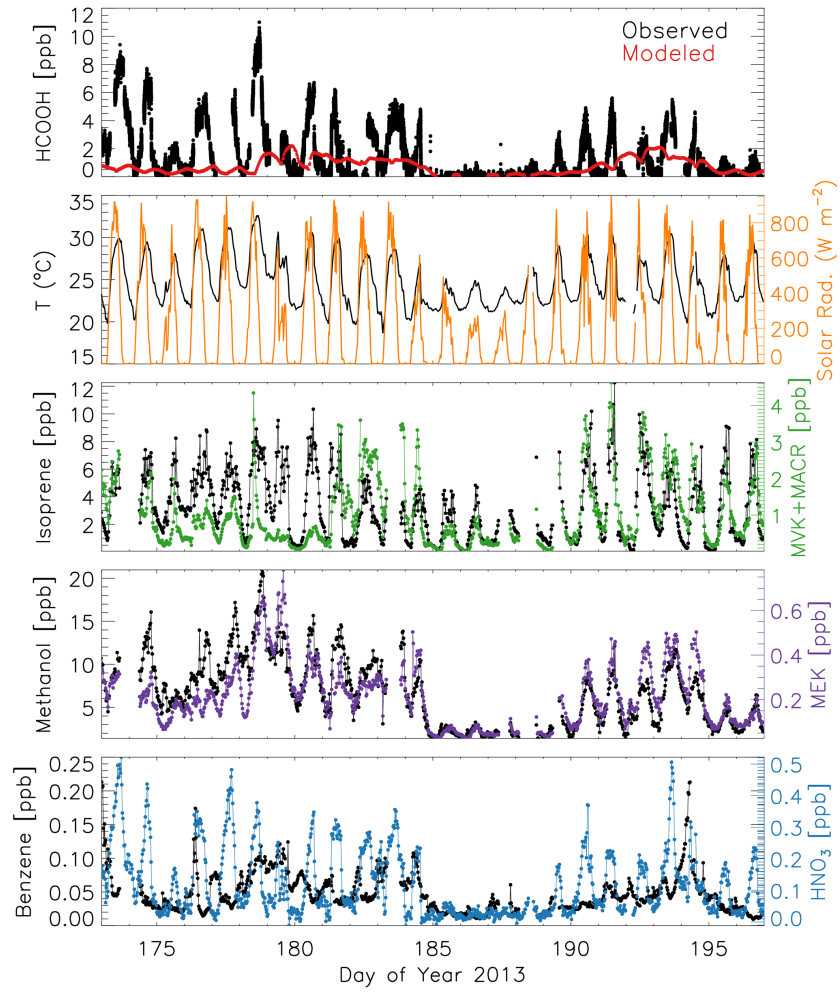

Figure 6. Timeline of chemical and meteorological measurements during the SOAS campaign (June-July 2013) near Brent AL, USA. The measured concentrations of $\mathrm{HCOOH}$ in black are compared to the simulated values in red.

ica. However, these findings leave room for a comparable per-reaction yield of $\mathrm{HCOOH}$ for both biogenic and anthropogenic VOCs, when one considers the emission disparity between the two. Biogenic VOCs have been estimated to account for approximately $88 \%$ of the total (anthropogenic + biogenic) VOC flux from North America in carbon units (Millet et al., 2008a), comparable to the mean biogenic contribution to $\mathrm{HCOOH}$ derived above. In fact, similar amounts of $\mathrm{HCOOH}(\sim 2 \mathrm{ppb})$ were recently observed during wintertime in the Uintah Basin (Utah, US), where hydrocarbon reactivity is dominated by alkanes and aromatics associated with oil and gas operations, and during summertime in Los Angeles (CA, US), where isoprene and unsaturated anthropogenic compounds make up the major part of the reactivity (Yuan et al., 2015). Production of $\mathrm{HCOOH}$ (and likely other carboxylic acids) appears therefore to be a ubiquitous feature of atmospheric hydrocarbon oxidation across a range of precursor types.

\subsection{Drivers of temporal variability in $\mathrm{HCOOH}$}

\subsubsection{SOAS ground site, Alabama}

Figure 6 shows concentrations of $\mathrm{HCOOH}$ and related species measured at the SOAS ground site in Alabama during 


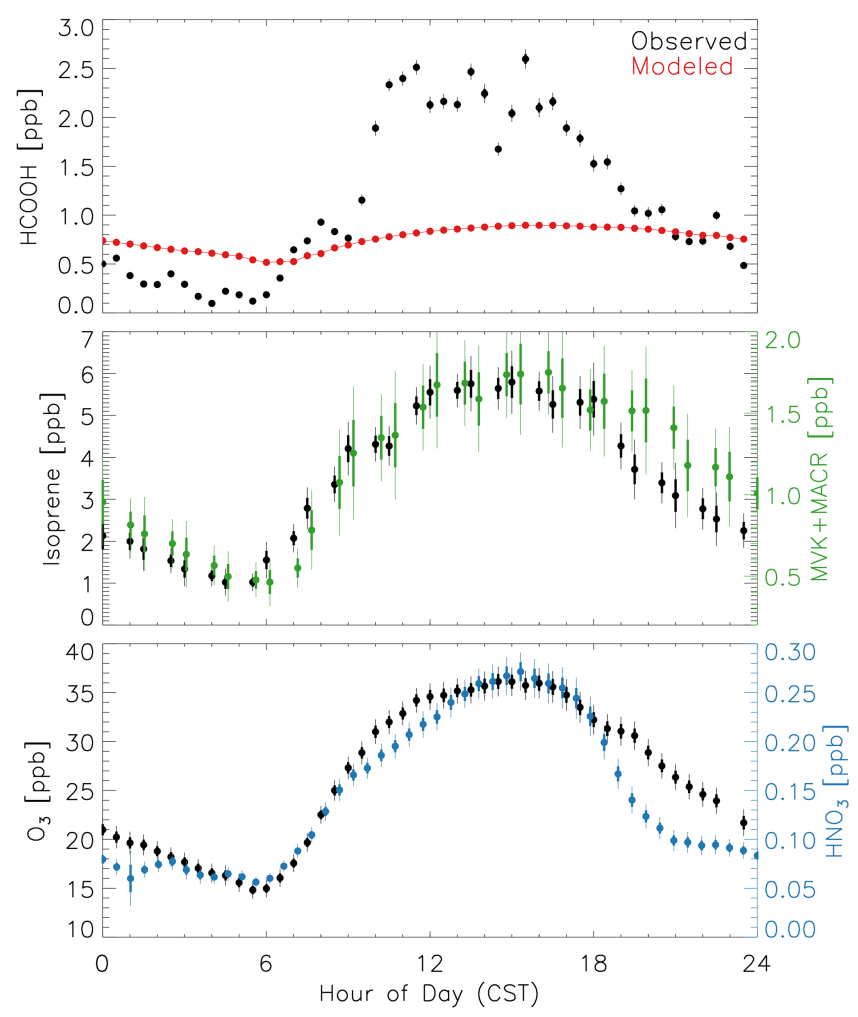

Figure 7. Diurnal cycle of $\mathrm{HCOOH}$ and related species as measured during SOAS. Error bars indicate \pm 1 (thick) and \pm 2 (thin) standard errors about the observed mean (points).

June and July 2013. This site is located in a mixed deciduous forest $8 \mathrm{~km}$ from the small cities of Brent and Centreville (combined population 7700). $\mathrm{HCOOH}$ concentrations ranged from near-zero to more than $10 \mathrm{ppb}$ during the SOAS study, with strong diurnal fluctuations. The GEOS-Chem simulation is unable to reproduce the dynamic range seen in the measurements, and exhibits a low bias (on average $3 \times$ ) that is consistent with the SENEX comparisons above.

We also see in Fig. 6 substantial day-to-day variability in atmospheric $\mathrm{HCOOH}$ driven by meteorological shifts. $\mathrm{HCOOH}$ concentrations are generally elevated during the warm and sunny conditions that prevailed for much of the period shown in the figure, but drop dramatically during cooler and cloudy days (e.g., 185-189). As shown in Fig. 6, these patterns mirror a number of other biogenic (e.g., methanol) and secondary (e.g., MEK, $\mathrm{HNO}_{3}$ ) compounds measured at the site. In fact, the strongest $\mathrm{HCOOH}$ correlation at SOAS is seen for $\mathrm{HNO}_{3}$ with $R=0.78$, followed closely by methanol at $R=0.74$, likely reflecting their common drivers of variability - sunlight-driven production and surface uptake/deposition.

Figure 7 shows mean diurnal cycles for $\mathrm{HCOOH}$ and selected other tracers over the entire SOAS campaign. In the case of $\mathrm{HCOOH}$, we see a pronounced morning increase that parallels that of isoprene and appears to slightly pre- cede that of MVK+MACR. Following a peak in the afternoon, $\mathrm{HCOOH}$ concentrations drop throughout the evening and night at a rate intermediate between $\mathrm{O}_{3}$ and $\mathrm{HNO}_{3}$. The GEOS-Chem simulation does not reproduce this large diurnal amplitude: $\mathrm{HCOOH}$ concentrations are overestimated at night, the prompt morning increase seen in the data is delayed and much too weak, daytime concentrations are underestimated, and the strong evening decline is not captured.

Errors in the model mixing heights may contribute to the above discrepancies, but cannot be the main explanation. We see in Fig. S3 that the GEOS-FP mixing heights for this location are generally too high during the day, and at times appear too low at night. The daytime bias will exacerbate the model $\mathrm{HCOOH}$ underestimate at that time; however, the $\mathrm{HCOOH}$ discrepancy is too great to be rectified by a $30-50 \%$ mixing height correction. Furthermore, a model underestimate of the nocturnal boundary layer depth should lead to an overprediction of near-surface $\mathrm{HCOOH}$ deposition and depletion at night, whereas we see in Fig. 7 a clear underprediction of this sink.

The prompt early-morning $\mathrm{HCOOH}$ increase seen during SOAS would seem to implicate direct emissions rather than photochemical production, since the rise occurs simultaneously with that of isoprene. However, we believe this behavior is partly driven by a combination of residual layer entrainment and increasing photochemical production over the course of the morning. The top panel of Fig. 8 shows $\mathrm{HCOOH}$ measurements during a nighttime SENEX flight on 2 July 2013 over Alabama and Tennessee. In the vicinity of the SOAS site, $\mathrm{HCOOH}$ concentrations aloft are 1.5-2.7 ppb, whereas concentrations at the ground drop to near-zero over the course of the night due to deposition within the shallow surface layer. This elevated residual layer $\mathrm{HCOOH}$ is then entrained into the $\mathrm{HCOOH}$-depleted air at the surface as the mixed layer develops after sunrise. We see similar behavior in Fig. 7 for $\mathrm{O}_{3}$ and $\mathrm{HNO}_{3}$. In a further manifestation of this dynamic, SOAS featured several nights with simultaneous enhancements of $\mathrm{HCOOH}$ and $\mathrm{O}_{3}$ associated with episodic downmixing of residual layer air.

Figure 8 (bottom panels) also shows mean vertical profiles for $\mathrm{HCOOH}$ and other VOCs measured during the same SENEX night flight. We see an inverted $\mathrm{HCOOH}$ vertical profile at night, due to surface uptake, that is not present in the model. The same model-measurement disparity is apparent for $\mathrm{MVK}+\mathrm{MACR}, \mathrm{HCHO}$, and $\mathrm{CH}_{3} \mathrm{COOH}$, though to a lesser degree. We thus have a reversal of the vertical gradient of $\mathrm{HCOOH}$ and other oxygenated VOCs between the day and night. This progression can be seen in the top panel of Fig. 8: early in the evening (prior to 183.10 UTC), low-altitude flight segments are accompanied by elevated $\mathrm{HCOOH}$, and vice versa. Later in the night, the situation has reversed, with the high altitude segments generally associated with more elevated $\mathrm{HCOOH}$ concentrations.

The model's inability to capture the evening $\mathrm{HCOOH}$ decline (Fig. 7) and the nocturnal vertical gradient (Fig. 8) im- 

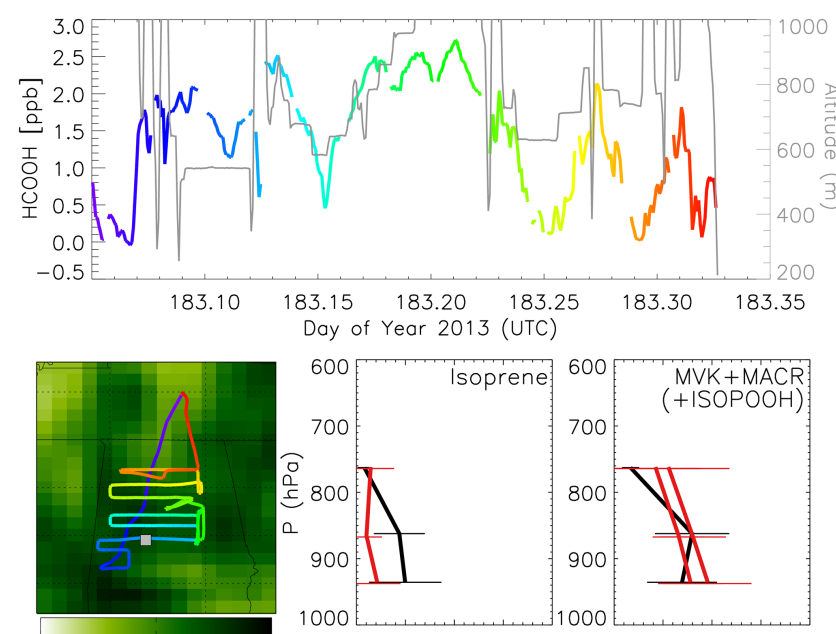

Day of Year 2013 (UTC)
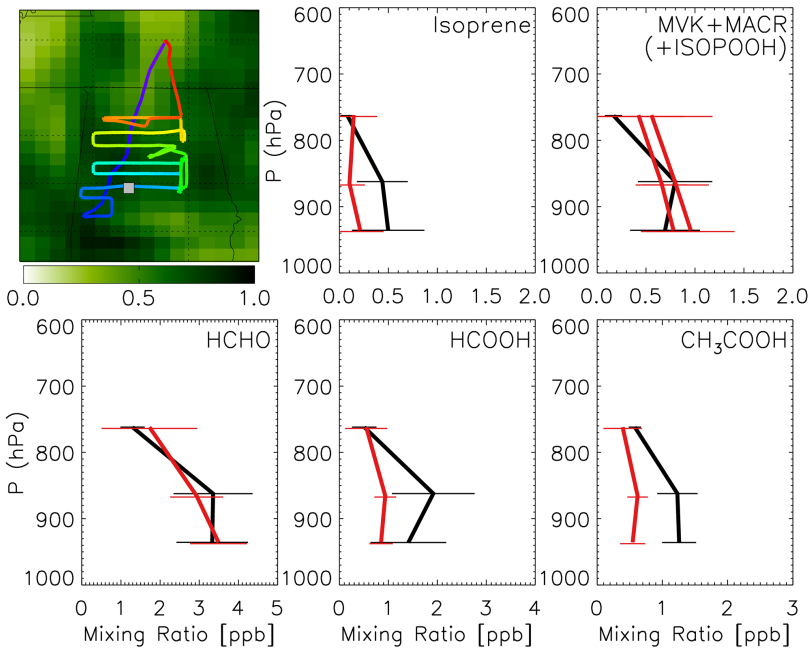

Figure 8. Nighttime measurements of $\mathrm{HCOOH}$ and related species over the US Southeast. Top panel: timeline of $\mathrm{HCOOH}$ and altitude measurements during a SENEX flight on the night of 12 July. The $\mathrm{HCOOH}$ trace is colored by time of day. Middle left: map of the SENEX flight track over TN and AL with the same color coding. The location of the SOAS ground site is indicated by the grey square. Also plotted (in green) is the percentage tree cover according to CLM4 (Oleson et al., 2010). Remaining panels: vertical profiles of $\mathrm{HCOOH}$ and related species as measured (black) and simulated (red) during this flight. Horizontal lines show the standard deviation of concentration in each altitude bin. Fresh biomass burning $\left(\mathrm{CH}_{3} \mathrm{CN}>225 \mathrm{ppt}\right)$ and pollution $\left(\mathrm{NO}_{x} / \mathrm{NO}_{y}\right.$ $>0.4$ or $\mathrm{NO}_{2}>4 \mathrm{ppb}$ ) plumes have been removed prior to plotting. Separate lines are shown for the simulated abundance of MVK+MACR and MVK+MACR plus isoprene hydroxyhydroperoxides (aka ISOPOOH), which can interfere with MVK+MACR measurements (Liu et al., 2013).

plies (i) a substantial underestimate of the $\mathrm{HCOOH}$ surface sink, or (ii) overly vigorous model mixing with overlying air during the night (thus replenishing $\mathrm{HCOOH}$ from aloft). The former could arise for dynamical (e.g., an overestimate of the aerodynamic and quasi-laminar resistances to deposition) or chemical (e.g., consumption of $\mathrm{HCOOH}$ by SCIs or other species) reasons. However, it cannot be due to an underestimate of the surface resistance for $\mathrm{HCOOH}$ itself, since as shown in Sect. 4.3 replacing the $\mathrm{HCOOH}$ deposition velocity with that for $\mathrm{HNO}_{3}$ does not resolve the model bias in this regard.
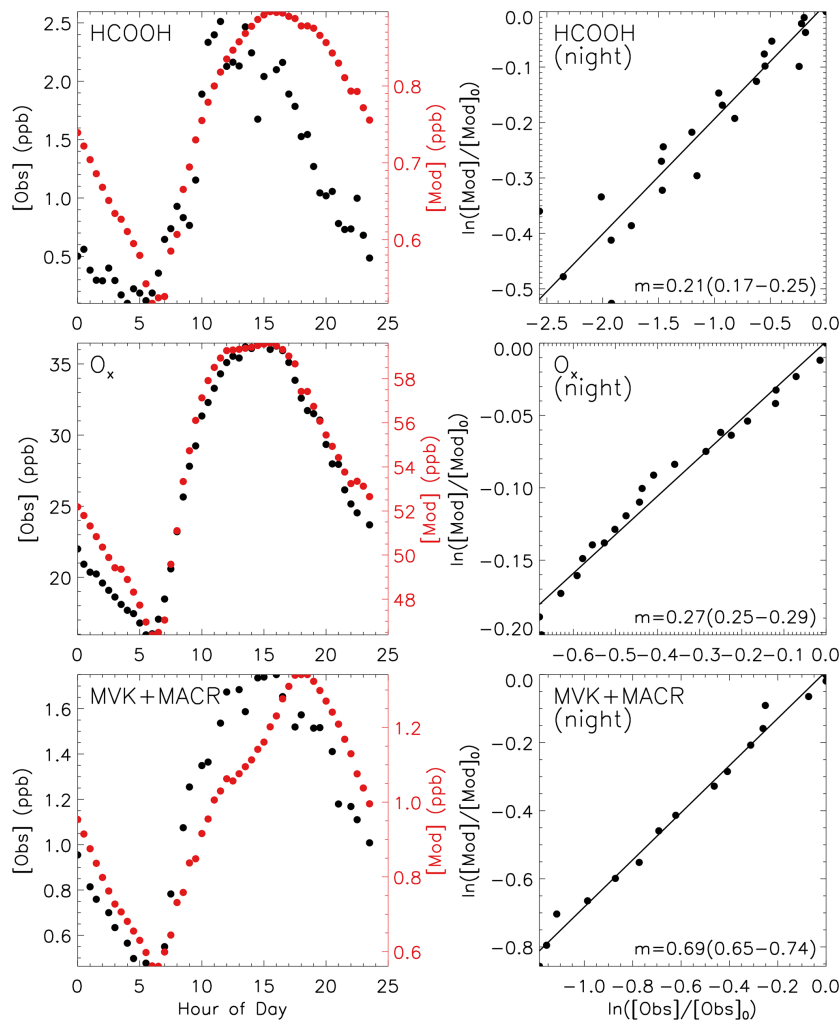

Figure 9. Diurnal amplitude of $\mathrm{HCOOH}, \mathrm{O}_{x}\left(\mathrm{O}_{3}+\mathrm{NO}_{2}\right)$ and MVK+MACR during SOAS. Left column: mean diurnal cycle of these species as measured (black) and modeled (red) over the course of the campaign. Right column: comparison of the mean modeled versus measured nighttime (19:00-06:00 LST) decay rates for the same species, plotted on a logarithmic scale. Numbers inset give the major axis slope with $95 \%$ confidence interval.

Figure 9 compares the modeled and measured nocturnal (19:00-06:00 LST) decay of $\mathrm{HCOOH}, \mathrm{O}_{x}\left(\mathrm{O}_{3}+\mathrm{NO}_{2}\right)$, and $\mathrm{MVK}+\mathrm{MACR}$ as an average over the SOAS field campaign. Data are plotted on logarithmic axes; the slope then estimates the model : observed ratio of deposition loss frequencies (assuming deposition is the dominant process driving the nighttime decline). We see that the effect of deposition on the ambient nighttime $\mathrm{HCOOH}$ concentrations is underestimated in the model by a factor of 4-5. However, a similar bias is apparent for $\mathrm{O}_{x}$. This suggests a general dynamical bias in the model rather than anything particular to $\mathrm{HCOOH}$, or, perhaps, a chemical sink for both $\mathrm{O}_{x}$ and $\mathrm{HCOOH}$ in surface air. A possibility for the latter is terpenoids that consume $\mathrm{O}_{3}$, generating SCI that can then consume or produce $\mathrm{HCOOH}$. Figure 9 also shows that, unlike $\mathrm{HCOOH}$ and $\mathrm{O}_{x}$, the model slope for MVK+MACR is only $30 \%$ lower than observed.

Overall, we see a strong diurnal cycle in $\mathrm{HCOOH}$ at the surface, driven by depletion in a shallow surface layer at night, and entrainment of $\mathrm{HCOOH}$-enriched residual layer air plus photochemical production/direct emissions during the day. These dynamics are not captured by the model, but 
there is inconsistency in model performance for $\mathrm{HCOOH}$ and $\mathrm{O}_{x}$ versus MVK+MACR. Improved constraints on surface uptake is a major need to improve our understanding of oxygenated VOCs and other trace gases. If dry deposition of $\mathrm{HCOOH}$ is in fact underestimated by the model, the magnitude of its missing source becomes proportionately larger.

\subsubsection{SLAQRS ground site, Greater St. Louis, Missouri-Illinois}

The SLAQRS study (August-September 2013) was based in East St. Louis, IL, within the Greater Saint Louis metropolitan area. The edge of the Ozark Plateau, one of the global hotspots for isoprene emission (and referred to as the "isoprene volcano"; Wiedinmyer et al., 2005) lies $\sim 35 \mathrm{~km}$ to the south and west of the site. To the north and east lie the predominantly non-isoprene-emitting agricultural landscapes of northern Missouri, southern Illinois, and Iowa. As Fig. 10 shows, the transport regime during the study shifted between northeasterly winds (or stagnant conditions) with low isoprene concentrations, and southwesterly winds that brought heavily isoprene-impacted air masses into the city (up to $8 \mathrm{ppb}$ of isoprene transported from the Ozarks). Because of these regime shifts the site provides a unique opportunity for examining the role of biogenic VOCs in a polluted urban area.

Figure 11 shows the mean diurnal cycle as a function of wind direction for a number of species measured during SLAQRS. We see the highest concentrations of anthropogenic compounds such as $\mathrm{CO}$ and benzene when winds are from the northeast (partly reflecting an association with low wind speeds). On the other hand, elevated amounts of isoprene and MVK+MACR are specifically associated with southwesterly winds. Peak concentrations occur at night because of rapid daytime photooxidation during transit from the Ozarks.

Also plotted in Fig. 11 are $\mathrm{HCOOH}$ and $\mathrm{CH}_{3} \mathrm{COOH}$. In both cases we see high concentrations (several ppb) from all sectors, but the highest amounts clearly occur with the southwesterly winds that also bring elevated isoprene and other biogenic oxidation products. $\mathrm{HCOOH}$ and $\mathrm{CH}_{3} \mathrm{COOH}$ are longer lived than isoprene and $\mathrm{MVK}+\mathrm{MACR}$ and are not depleted to the same degree during transport; concentrations thus typically peak in the late afternoon rather than at night.

The hottest conditions during SLAQRS occurred with southwesterly winds, raising the question of whether the above $\mathrm{HCOOH}$ and $\mathrm{CH}_{3} \mathrm{COOH}$ enhancements merely reflect accelerated chemistry at high temperatures, or a correlating dynamical effect (e.g., stagnation) rather than a biogenic origin. An examination of two other compounds with a substantial (acetone) to dominant (MEK) secondary anthropogenic source, and comparable photochemical lifetimes to $\mathrm{HCOOH}$ and $\mathrm{CH}_{3} \mathrm{COOH}$ ( $>1$ day at $\mathrm{OH}=10^{7}$ molec $\mathrm{cm}^{-3}$ ), reveals that this is not the case. While we do see higher amounts of acetone and MEK with southwesterly winds (Fig. 11),
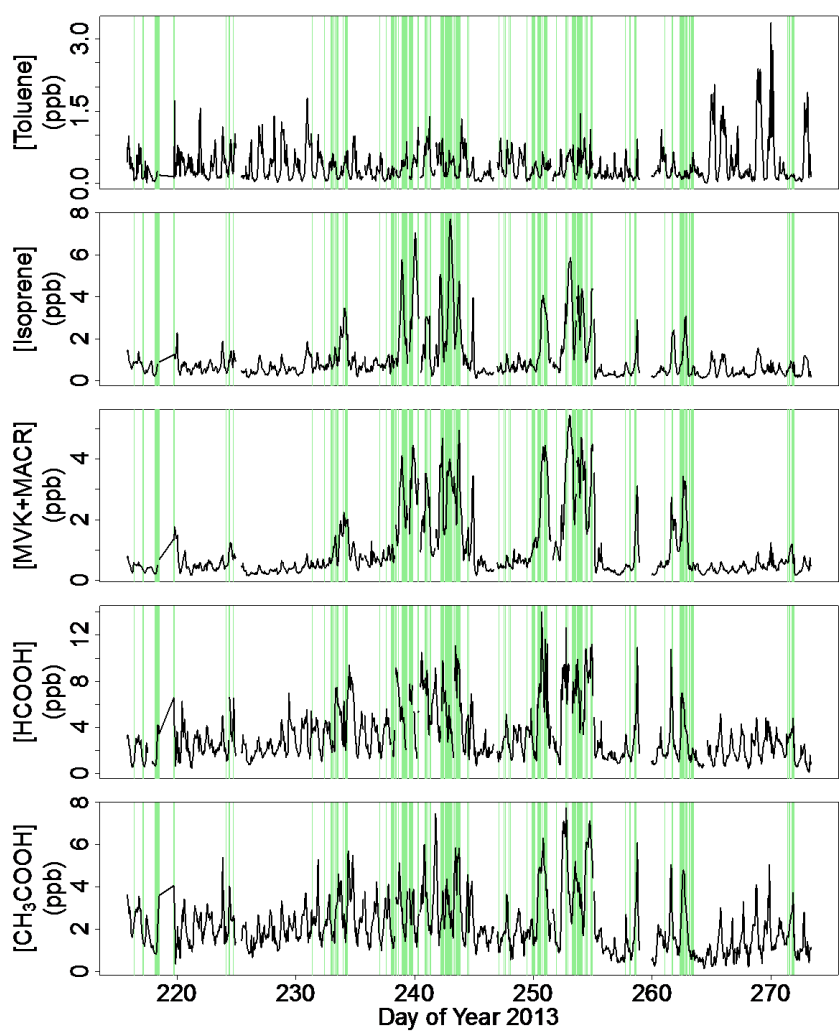

Figure 10. Timeline of chemical measurements during the SLAQRS campaign (August-September 2013) in Greater St. Louis MO-IL, USA. Green shading indicates time periods with southwesterly winds $\left(180-270^{\circ}\right.$; wind speed $\left.>0.5 \mathrm{~m} \mathrm{~s}^{-1}\right)$ from the Ozark Plateau.

the diurnal cycle is strikingly different than $\mathrm{HCOOH}$ and $\mathrm{CH}_{3} \mathrm{COOH}$. Here, the concentrations peak following the morning and evening rush hours along with $\mathrm{CO}$ and toluene (Fig. S4), rather than in the late afternoon.

The SLAQRS data set is thus consistent with SENEX and SOAS in pointing towards a major biogenic source of formic and acetic acids. However, while the highest ambient levels are clearly linked to biogenic sources, concentrations of several ppb are seen even when isoprene is low. This is consistent with other measurements in urban areas (e.g., Le Breton et al., 2012; Veres et al., 2011) and in an oil and gas producing area (Yuan et al., 2015). The overall indication is of a ubiquitous chemical source of $\mathrm{HCOOH}$ (and likely other carboxylic acids) across a range of precursors. Since biogenic emissions dominate the reactive carbon budget, they would then also provide the bulk of the precursor material for $\mathrm{HCOOH}$ and related compounds. 


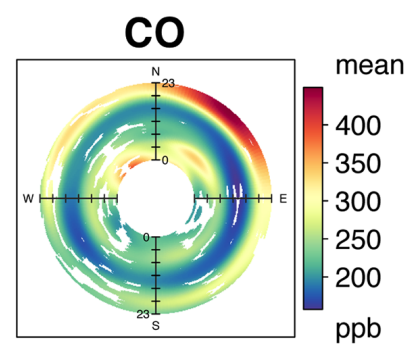

Isoprene

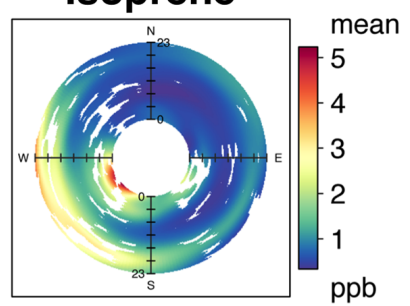

$\mathrm{HCOOH}$
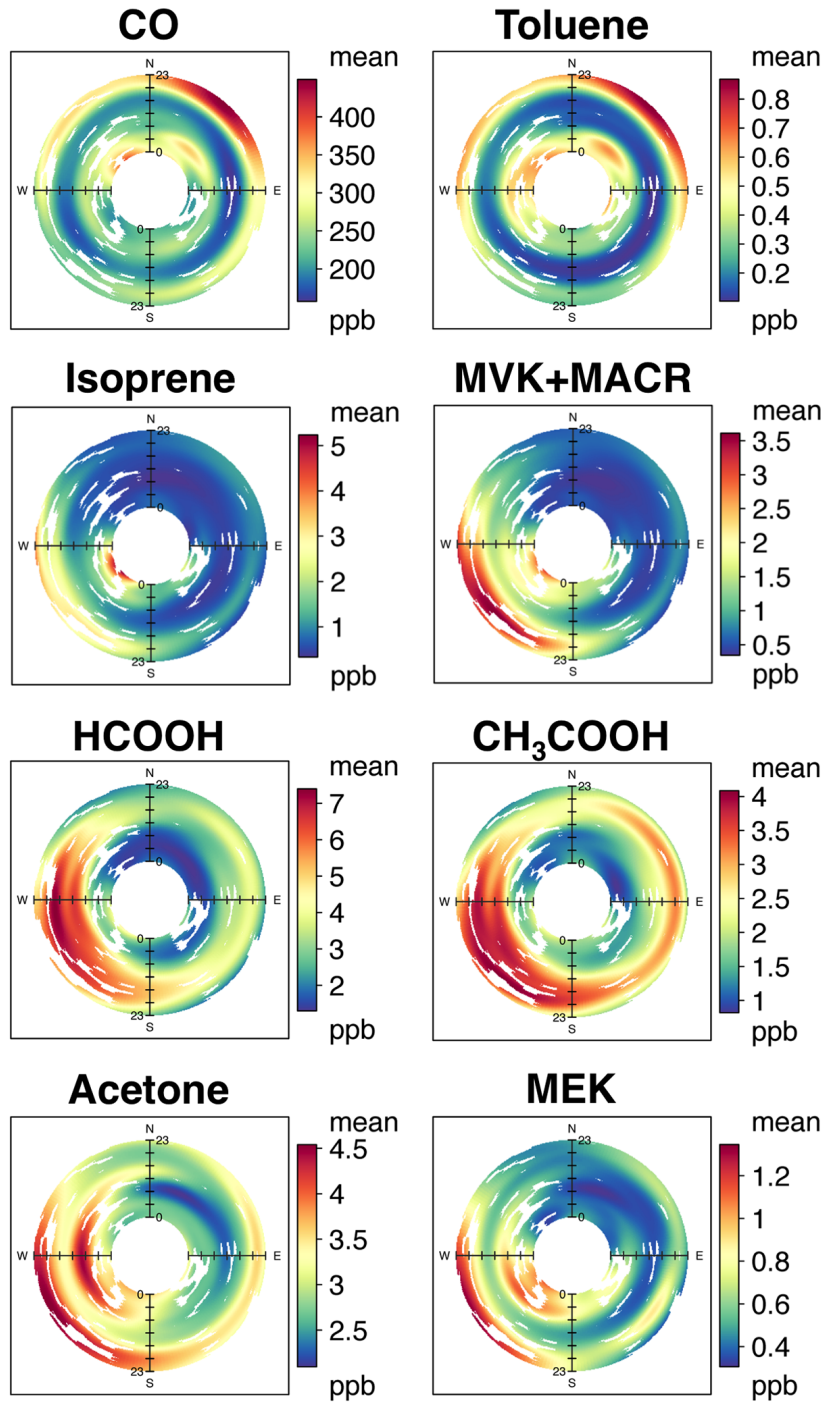

Figure 11. Diurnal cycle of $\mathrm{HCOOH}$ and related chemicals during SLAQRS as a function of wind direction, with time of day (LST) plotted radially. Plots generated using open air (Carslaw and Ropkins, 2012).

\section{Potential importance of other $\mathrm{HCOOH}$ source and sink pathways}

In this section we examine the sensitivity of atmospheric $\mathrm{HCOOH}$ to a range of other possible source and sink pathways, and assess the potential importance of each in light of the large budget gaps discussed above.

\subsection{SCI reaction with carboxylic acids}

Recent advances in synthesizing and detecting SCIs (Taatjes et al., 2008; Welz et al., 2012) have enabled significant (and quickly evolving) progress in understanding their atmospheric chemistry. For instance, SCIs may also provide a sink as well as a source of $\mathrm{HCOOH}$ and other carboxylic acids: Welz et al. (2014) measured rate coefficients for a set of $\mathrm{SCI}+\mathrm{HCOOH}$ and $\mathrm{SCI}+\mathrm{CH}_{3} \mathrm{COOH}$ reactions and derived values ranging from $1.1-5 \times 10^{-10} \mathrm{~cm}^{3} \mathrm{molec}^{-1} \mathrm{~s}^{-1}$. Based on their results, we performed a sensitivity simulation that includes this chemistry with rate coefficients of 1.1, 2.5, and $1.0 \times 10^{-10} \mathrm{~cm}^{3} \mathrm{molec}^{-1} \mathrm{~s}^{-1}$, respectively, for the reaction of $\mathrm{CH}_{2} \mathrm{OO}, \mathrm{CH}_{3} \mathrm{CHOO}$, and other SCIs with carboxylic acids. This chemistry has the effect of both increasing the sink and decreasing the source of $\mathrm{HCOOH}$, since fewer SCIs go on to produce carboxylic acids. However, we find that the overall effects are modest. Globally, the relative importance of chemical loss and deposition as $\mathrm{HCOOH}$ sinks is shifted slightly, with the former increasing by $\sim 11 \%$ and the latter decreasing by $\sim 6 \%$ compared to the amounts in Fig. 1. The overall $\mathrm{HCOOH}$ source is diminished slightly $(4 \%)$. Figure 12 shows that the SCI + carboxylic acid chemistry reduces the mean simulated $\mathrm{HCOOH}$ abundance in surface air by $10-20 \%$ for SENEX and SOAS relative to the base model. We also find that this chemistry cannot explain the rapid nighttime decay of $\mathrm{HCOOH}$ observed during SOAS: the rate of decline is not significantly changed from the basecase slope in Fig. 9.

Along with these atmospheric implications, the Welz et al. (2014) findings may also imply that reported $\mathrm{HCOOH}$ yields from laboratory ozonolysis studies are biased low (particularly for experiments done under dry conditions), due to suppression of secondary organic acids by SCIs.

\subsection{SCI reaction with water vapor and self-reaction}

The predominant sink of the $\mathrm{CH}_{2} \mathrm{OO} \mathrm{SCI}$ in our basecase simulation is reaction with water vapor, and esti-

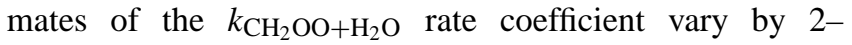
3 orders of magnitude (Newland et al., 2015; Stone et al., 2014). However, we find that replacing our default rate $\left(k_{\mathrm{CH}_{2} \mathrm{OO}+\mathrm{H}_{2} \mathrm{O}}=10^{-17} \mathrm{~cm}^{3} \mathrm{molec}^{-1} \mathrm{~s}^{-1}\right.$; Jenkin et al., 1997; Saunders et al., 2003) with recent higher $\left(1.3 \times 10^{-15} \mathrm{~cm}^{3} \mathrm{molec}^{-1} \mathrm{~s}^{-1}\right.$; Newland et al., 2015) and lower $\left(5.4 \times 10^{-18} \mathrm{~cm}^{3} \mathrm{molec}^{-1} \mathrm{~s}^{-1}\right.$; Stone et al., 2014) estimates has a negligible impact on the simulated $\mathrm{HCOOH}$ budget. This is because the competing model sinks for $\mathrm{CH}_{2} \mathrm{OO}$ $\left(\mathrm{SO}_{2}, \mathrm{CO}, \mathrm{NO}, \mathrm{NO}_{2}\right.$ - rates follow MCMv3.2; Jenkin et al., 1997; Saunders et al., 2003) are sufficiently slow that reaction with water dominates, even at $k_{\mathrm{CH}_{2} \mathrm{OO}+\mathrm{H}_{2} \mathrm{O}}=5.4 \times$ $10^{-18} \mathrm{~cm}^{3} \mathrm{molec}^{-1} \mathrm{~s}^{-1}$. For the same reason, including the $\mathrm{CH}_{2} \mathrm{OO}$ self-reaction at $8 \times 10^{-11} \mathrm{~cm}^{3} \mathrm{molec}^{-1} \mathrm{~s}^{-1}$ (Ting et al., 2014) has no appreciable effect on the simulated distribution of $\mathrm{HCOOH}$.

It is worth pointing out, however, that Welz et al. (2012) and Stone et al. (2014) were not able to directly measure the $\mathrm{CH}_{2} \mathrm{OO}+\mathrm{H}_{2} \mathrm{O}$ rate coefficient, instead reporting an upper limit $\left(<4 \times 10^{-15}\right.$ and $<9 \times 10^{-17} \mathrm{~cm}^{3}$ molec $^{-1} \mathrm{~s}^{-1}$, respectively). If the actual rate is significantly slower than the values applied here (or the rates for competing SCI reactions are faster; e.g., Welz et al., 2012) then the role of $\mathrm{CH}_{2} \mathrm{OO}+$ 

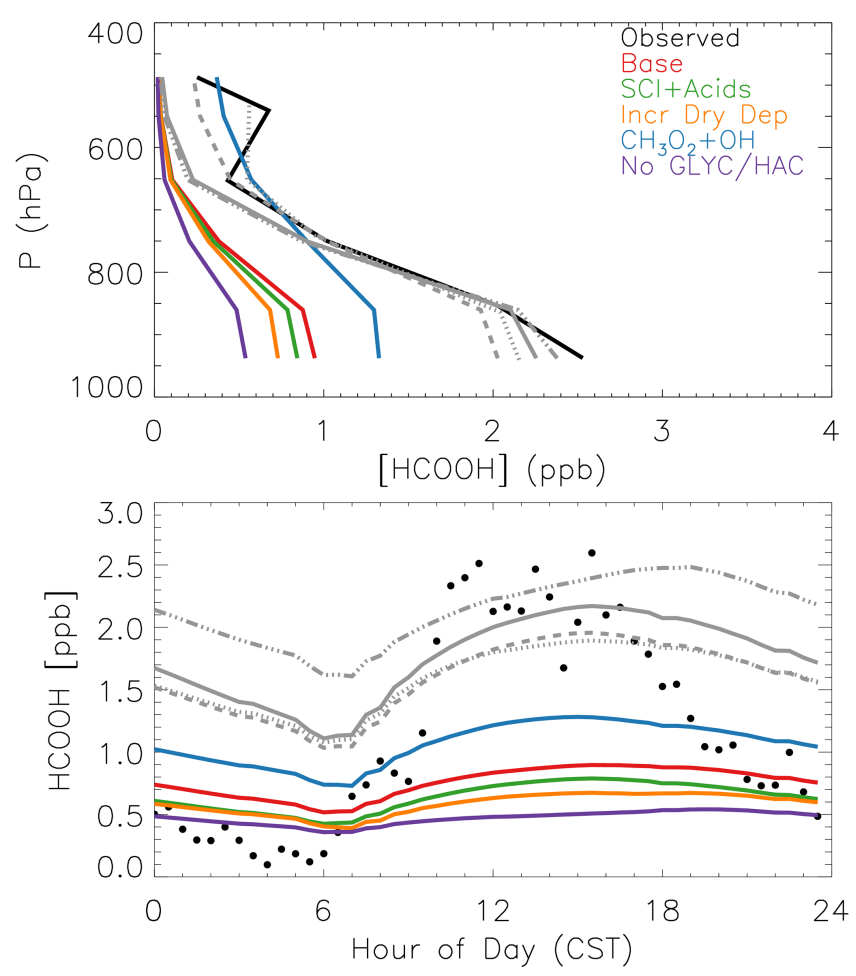

Figure 12. Sensitivity of atmospheric $\mathrm{HCOOH}$ to selected sources and sinks in GEOS-Chem. Shown in black is the mean $\mathrm{HCOOH}$ vertical profile observed during SENEX (top panel) and the mean $\mathrm{HCOOH}$ diurnal cycle observed during SOAS (bottom panel). Colored lines show the corresponding simulated amounts from GEOS-Chem for selected sensitivity runs described in the text. Base: base-case simulation; SCI+Acids: including reactions between SCIs and carboxylic acids (Welz et al., 2014); Incr Dry Dep: setting the $\mathrm{HCOOH}$ dry deposition velocity equal to that of $\mathrm{HNO}_{3}$; $\mathrm{CH}_{3} \mathrm{O}_{2}+\mathrm{OH}$ : including reaction between $\mathrm{CH}_{3} \mathrm{O}_{2}$ and $\mathrm{OH}$ (Bossolasco et al., 2014) with a $100 \%$ yield of $\mathrm{CH}_{2} \mathrm{OO}$; No GLYC/HAC: excluding $\mathrm{HCOOH}$ from isoprene-derived glycoaldehyde and hydroxyacetone. Grey lines show example model adjustments that can fit the mean observed SENEX profile. Solid grey: scaled source from isoprene oxidation $(3 \times$ base-case); dot-dashed grey: scaled source from direct biogenic emissions ( $26 \times$ base-case); dotted grey: scaled source from isoprene $(1.8 \times$ base-case $)$ combined with a ubiquitous chemical source of $\mathrm{HCOOH}$; dashed grey: scaled source from isoprene $(2.3 \times$ base-case $)$ combined with a $56 \% \mathrm{CH}_{2} \mathrm{OO}$ yield from $\mathrm{CH}_{3} \mathrm{O}_{2}+\mathrm{OH}$. See text for details.

$\mathrm{H}_{2} \mathrm{O}$ as a source of $\mathrm{HCOOH}$ would decrease. Likewise, the importance of the SCI + carboxylic acid reactions above will depend directly on the rate of competing SCI + water vapor reactions.

\subsection{Dry deposition}

The strong temporal decline (Fig. 9) and vertical gradient (Fig. 8) of $\mathrm{HCOOH}$ at night measured during SOAS and SENEX are not captured by the model, perhaps indicating an underestimate of the $\mathrm{HCOOH}$ deposition velocity. To test whether this is the case, we carried out a sensitivity analysis with the $\mathrm{HCOOH}$ deposition velocity for each time and model location set to the corresponding value computed for $\mathrm{HNO}_{3}$ (a highly soluble gas that undergoes rapid and irreversible deposition). This leads to a $5 \%$ drop in the global $\mathrm{HCOOH}$ burden and a 20-25\% decrease in the mean surface air concentrations simulated for SENEX and SOAS (Fig. 12). However, we also see in Fig. 12 that the rapid nighttime decrease is still not captured by the model, and the corresponding decay rate is statistically unchanged from the base-case simulation (Fig. 9). It therefore is not feasible to rectify this issue simply based on the modeled $\mathrm{HCOOH}$ surface resistance to deposition. This, combined with the fact that the nighttime decay in $\mathrm{O}_{x}$ during SOAS is underestimated by a similar amount, suggests a more general dynamical bias in the model related to the diurnal cycle of boundary layer mixing (or possibly a vigorous nighttime chemical sink for both species).

\subsection{Additional sources of $\mathrm{HCOOH}: \mathrm{HCHO}+\mathrm{HO}_{2}$, $\mathrm{CH}_{3} \mathrm{O}_{2}+\mathrm{OH}$}

Reversible addition of $\mathrm{HO}_{2}$ to $\mathrm{HCHO}$ produces the $\mathrm{HOCH}_{2} \mathrm{OO}$ radical, which can go on to form $\mathrm{HCOOH}$ (Jenkin et al., 2007). We find that implementing this chemistry in the same manner as Paulot et al. (2011) leads to a $\sim 4 \%$ global increase in the photochemical source of $\mathrm{HCOOH}$. Because of the strong temperature dependence of the reverse reaction (Atkinson et al., 2006), the $\mathrm{HCOOH}$ increase manifests mainly in the upper troposphere where its lifetime is long, and the increase in the simulated global burden $(17 \%)$ is thus larger than that in the source. Simulated concentrations in the lower free troposphere and in the boundary layer are not significantly affected by the $\mathrm{HO}_{2}+$ $\mathrm{HCHO}$ reaction, and the model-measurement comparisons discussed above are statistically unchanged compared to the base-case run.

On the other hand, the $\mathrm{CH}_{3} \mathrm{O}_{2}+\mathrm{OH}$ reaction is a major potential lever on the atmospheric abundance of $\mathrm{HCOOH}$, depending on the reaction products. Including this reaction at the recently reported rate of $k_{\mathrm{CH}_{3} \mathrm{O}_{2}+\mathrm{OH}}=2.8 \times$ $10^{-10} \mathrm{~cm}^{3} \mathrm{molec}^{-1} \mathrm{~s}^{-1}$ (Bossolasco et al., 2014), and assuming that the $\mathrm{CH}_{2} \mathrm{OO}$ Criegee intermediate is formed with $100 \%$ yield, leads to a $>5 \times$ increase in the simulated global burden of $\mathrm{HCOOH}$. The free tropospheric $\mathrm{HCOOH}$ bias seen in the base-case simulation during SENEX is eliminated (Fig. 12). However, the $\mathrm{HCOOH}$ source from $\mathrm{CH}_{3} \mathrm{O}_{2}+\mathrm{OH}$ is spatially diffuse and cannot account for the enhanced boundary layer concentrations measured during SOAS, SENEX, or SLAQRS. The daytime model underestimate during SOAS is reduced while the nighttime overestimate is increased (Fig. 12), and there is a slight degradation in the model correlation with the airborne SENEX data set ( $R=0.66)$ compared to the base-case run $(R=0.71)$. 

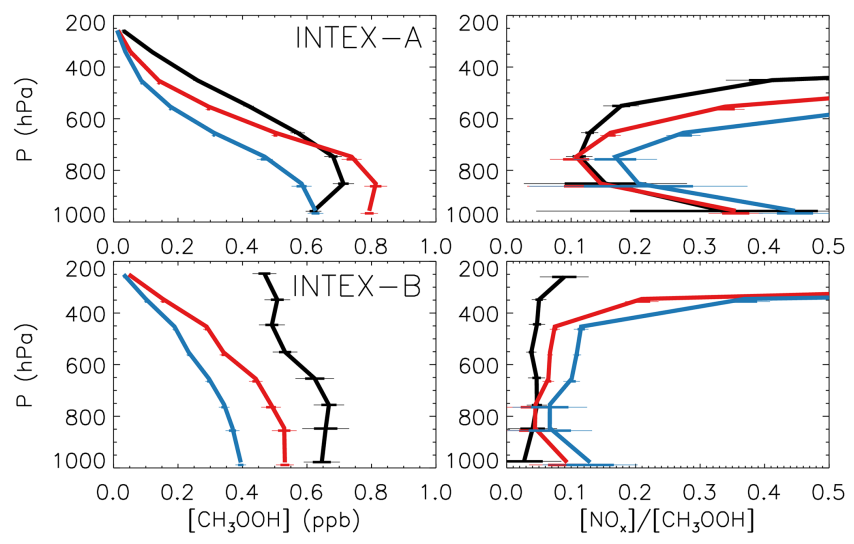

Figure 13. Vertical profiles of $\mathrm{CH}_{3} \mathrm{OOH}$ and the $\mathrm{NO}_{x}: \mathrm{CH}_{3} \mathrm{OOH}$ ratio over North America. Shown are the mean measured (black) and simulated (colored) values during the INTEX-A (Singh et al., 2006) and INTEX-B (Singh et al., 2009) flight campaigns. Red lines show results from the GEOS-Chem basecase simulation, while the blue lines show results from a sensitivity run that includes the $\mathrm{CH}_{3} \mathrm{O}_{2}+\mathrm{OH}$ reaction at $k_{\mathrm{CH}_{3} \mathrm{O}_{2}+\mathrm{OH}}=2.8 \times 10^{-10} \mathrm{~cm}^{3}$ molec $^{-1} \mathrm{~s}^{-1}$ (Bossolasco et al., 2014). Horizontal lines indicate \pm 1 (thick) and \pm 2 (thin) standard errors about the mean.

The above impacts depend both on the rate of the $\mathrm{CH}_{3} \mathrm{O}_{2}+$ $\mathrm{OH}$ reaction and on the product yields, which have yet to be directly measured. Here we have assumed that the reaction proceeds exclusively through $\mathrm{H}$-abstraction to yield $\mathrm{CH}_{2} \mathrm{OO}$, and this was shown to have a large impact on the atmospheric $\mathrm{HCOOH}$ budget. However, other reaction pathways are possible: O-atom abstraction to yield $\mathrm{CH}_{3} \mathrm{O}+\mathrm{HO}_{2}$, and $\mathrm{S}_{\mathrm{N}} 2$ substitution to yield $\mathrm{CH}_{3} \mathrm{OH}+\mathrm{O}_{2}$ (Archibald et al., 2009; Fittschen et al., 2014). The former would lead immediately to $\mathrm{HCHO}$ production (as in the $\mathrm{CH}_{3} \mathrm{O}_{2}+\mathrm{NO}$ pathway), while if the latter dominates it would require a major revision to present understanding of the global methanol budget (Millet et al., 2008b; Stavrakou et al., 2011; Wells et al., 2014). The $\mathrm{CH}_{2} \mathrm{OO}$ yield for the analogous $\mathrm{CH}_{3} \mathrm{O}_{2}+\mathrm{Cl}$ reaction has been estimated at $50 \%$ (Jungkamp et al., 1995; Maricq et al., 1994) to $90 \%$ (Daële and Poulet, 1996), while that for the $\mathrm{CH}_{3} \mathrm{O}_{2}+\mathrm{BrO}$ reaction was recently estimated at $\sim 80 \%$ (Shallcross et al., 2015).

In any case, based on the Bossolasco et al. (2014) results, oxidation of $\mathrm{CH}_{3} \mathrm{O}_{2}$ by $\mathrm{OH}$ would be an important reaction in low-NO environments where we would otherwise expect $\mathrm{CH}_{3} \mathrm{O}_{2}+\mathrm{HO}_{2}$ to predominate, yielding $\mathrm{CH}_{3} \mathrm{OOH}+\mathrm{O}_{2}$. Figure 13 shows mean vertical profiles of $\mathrm{CH}_{3} \mathrm{OOH}$ and the $\mathrm{NO}_{x}: \mathrm{CH}_{3} \mathrm{OOH}$ ratio for two aircraft campaigns where such data are available (INTEX-A and INTEX-B; Lee et al., 1995; Singh et al., 2006; Singh et al., 2009). We see that including the $\mathrm{CH}_{3} \mathrm{O}_{2}+\mathrm{OH}$ reaction at $2.8 \times 10^{-10} \mathrm{~cm}^{3} \mathrm{molec}^{-1} \mathrm{~s}^{-1}$ degrades the model simulation of both $\mathrm{CH}_{3} \mathrm{OOH}$ and the $\mathrm{NO}_{x}: \mathrm{CH}_{3} \mathrm{OOH}$ relationship for these data sets. This suggests either that the reported $\mathrm{CH}_{3} \mathrm{O}_{2}+\mathrm{OH}$ rate is too high, or the presence of some offsetting model error in the base-case run. Clearly, this chemistry has the potential to significantly alter our understanding of several key chemical budgets, and developing better constraints on the $\mathrm{CH}_{3} \mathrm{O}_{2}+\mathrm{OH}$ rate coefficient and the resulting products should be a high priority for future research.

\subsection{Isoprene chemistry}

Oxidation of glycoaldehyde and hydroxyacetone provides the largest isoprene-derived $\mathrm{HCOOH}$ source in the model, and our representation of this chemistry is based on the findings of Butkovskaya et al. (2006a, b). However, more recent work has failed to detect any significant $\mathrm{HCOOH}$ production by these pathways (Orlando et al., 2012). Excluding this source in the model decreases the mean surface concentrations during SENEX by 40-45\% (Fig. 12), and approximately doubles the model-measurement discrepancy (i.e., regression slope) seen during this campaign. This would imply an even larger missing source of atmospheric $\mathrm{HCOOH}$ than is otherwise required.

\section{Discussion and implications}

The analyses above clearly show a major model underestimate of $\mathrm{HCOOH}$ (and $\mathrm{CH}_{3} \mathrm{COOH}$ ) sources, a finding supported by other recent work (Le Breton et al., 2012; Stavrakou et al., 2012; Veres et al., 2011; Yuan et al., 2015). The fact that these organic acids are present in such large amounts in the continental troposphere, with sources that from available evidence are mainly photochemical, implies that some central aspect of the atmospheric VOC oxidation chain is not currently understood.

Based on the observed patterns of variability and tracertracer correlations discussed earlier, we infer that the missing $\mathrm{HCOOH}$ sources have a majority biogenic component. However, elevated $\mathrm{HCOOH}$ amounts are seen even in anthropogenically dominated air masses, and in the free troposphere, suggesting that other processes are also at play. To illustrate the magnitude of the inferred missing source, Fig. 12 shows (in grey) four example model adjustments that can fit the mean observed SENEX profile. These were derived by regressing the model-measurement residuals against the simulated source contributions to atmospheric $\mathrm{HCOOH}$.

- Explaining the boundary layer $\mathrm{HCOOH}$ measured during SENEX based solely on isoprene oxidation requires $\mathrm{a} \sim 3 \times$ increase in the model $\mathrm{HCOOH}$ yield (which is $13 \%$ is the base-case simulation) as shown in Fig. 12 (solid grey line). Accommodating such a large $\mathrm{HCOOH}$ yield would require a significant revision to other product yields in order to conserve carbon in the isoprene oxidation chain.

- Alternatively, explaining the SENEX observations solely on the basis of direct biogenic emissions of 
$\mathrm{HCOOH}$ would require on the order of a $26 \times$ increase in its biotic flux. Extrapolating this over the North American domain of Fig. S1 yields $\mathrm{HCOOH}$ emissions that are $27 \%$ those of isoprene on a mass basis $(8 \%$ on a carbon basis). However, we see in Fig. 12 that of these first two scenarios neither can explain the elevated free tropospheric concentrations of $\mathrm{HCOOH}$, nor can they account for the high $\mathrm{HCOOH}$ seen during low-isoprene periods in SLAQRS and in the Uintah Basin during winter (Yuan et al., 2015).

- An increased biogenic source of $\mathrm{HCOOH}$ (direct or secondary from isoprene/monoterpenes) plus some contribution from $\mathrm{CH}_{3} \mathrm{O}_{2}+\mathrm{OH}$ (yielding $\mathrm{CH}_{2} \mathrm{OO}$ and subsequently $\mathrm{HCOOH}$ ) could potentially explain the SENEX profile. For example, the dashed grey line in Fig. 12 shows the mean simulated $\mathrm{HCOOH}$ profile resulting from a $2.3 \times$ increase in the source from isoprene and a $56 \% \mathrm{CH}_{2} \mathrm{OO}$ yield from $\mathrm{CH}_{3} \mathrm{O}_{2}+\mathrm{OH}$ (or equivalently a $100 \% \mathrm{CH}_{2} \mathrm{OO}$ yield and a $44 \%$ reduction in $k_{\mathrm{CH}_{3} \mathrm{O}_{2}+\mathrm{OH}}$; Bossolasco et al., 2014). We are still left, however, with substantial anthropogenic $\mathrm{HCOOH}$ enhancements (e.g., as observed recently in St. Louis, London, and Utah) that cannot be explained by a diffuse source that is most important at low $\mathrm{NO}_{x}$.

- Figure 12 also shows the model $\mathrm{HCOOH}$ profile that would result from an increase in the source from isoprene combined with ubiquitous $\mathrm{HCOOH}$ production throughout the VOC oxidation cascade. Here, a 1.8 $\times$ increase in the $\mathrm{HCOOH}$ yield from isoprene and an aggregate weighted yield of $2 \%$ from the ensemble of $\mathrm{RO}_{2}+$ NO reactions achieves an approximate fit to the mean SENEX profile.

Overall, it appears that an increased $\mathrm{HCOOH}$ source from isoprene (or other biogenic source) combined with a widespread chemical source across a range of precursor types is most tenable as an explanation for the full suite of available atmospheric observations.

There are a number of key sources of uncertainty that need to be resolved to close the $\mathrm{HCOOH}$ budget and thus improve our overall understanding of VOC chemistry in the atmosphere. (i) The role of isoprene, and of other biogenic compounds such as monoterpenes, in $\mathrm{HCOOH}$ production needs to be quantified. There is conflicting laboratory evidence for the importance of glycoaldehyde/hydroxyacetone chemistry in this context, and as we have seen this has major implications for the $\mathrm{HCOOH}$ budget. As shown above, available atmospheric observations leave room for a substantially larger $\mathrm{HCOOH}$ source from isoprene oxidation than the $\sim 13 \%$ used here as base case (and which includes production from glycoaldehyde and hydroxyacetone). The analyses here cannot segregate isoprene oxidation from some other correlating $\mathrm{HCOOH}$ source such as direct surface emissions or terpene oxidation. In fact, Stavrakou et al. (2012) postulated on the basis of satellite observations from the Infrared Atmospheric Sounding Interferometer (IASI) that terpenoid emissions from boreal forests were a large source of atmospheric $\mathrm{HCOOH}$. However, given the magnitude of the required $\mathrm{HCOOH}$ source inferred here, isoprene as (by far) the largest source of reactive carbon to the atmosphere appears a probable candidate. (ii) The atmospheric chemistry of SCIs (in particular their rates of reaction with water vapor) needs to be better constrained in order to define their importance as carboxylic acid sources and sinks, and as oxidants of other critical atmospheric species (e.g., $\mathrm{SO}_{2}$ ). (iii) Reaction between $\mathrm{CH}_{3} \mathrm{O}_{2}$ and $\mathrm{OH}$ (Bossolasco et al., 2014) could be of significant importance for atmospheric chemistry, with implications for a number of key chemical budgets. Including this chemistry degrades the model simulation of $\mathrm{CH}_{3} \mathrm{OOH}$ and $\mathrm{NO}_{x}: \mathrm{CH}_{3} \mathrm{OOH}$, though this might reflect some offsetting model error (e.g., in the $\mathrm{CH}_{3} \mathrm{OOH}$ lifetime). Reducing the uncertainty in the $\mathrm{CH}_{3} \mathrm{O}_{2}+\mathrm{OH}$ reaction rate, and determining the product yields, is a high priority for future research. (iv) Finally, we have seen here that GEOS-Chem cannot capture the impact of deposition on surface air concentrations of $\mathrm{HCOOH}$. A similar issue is seen for $\mathrm{O}_{x}$, which may imply a common dynamical or chemical issue rather than a deposition underestimate specific to $\mathrm{HCOOH}$. In any case, developing a more robust representation of surface deposition (and associated boundary layer coupling) is needed to improve our understanding of land-atmosphere interactions and our ability to relate observed concentrations to sources.

\section{The Supplement related to this article is available online at doi:10.5194/acp-15-6283-2015-supplement.}

Acknowledgements. This research was supported by the National Science Foundation (grants \#1148951 and 0937004) and by the Minnesota Supercomputing Institute. We are indebted to JeanFrançois Müller, John Orlando, Carl Percival, Andrew Rickard, Paul Shepson, Domenico Taraborrelli, and Paul Wennberg for a number of illuminating discussions that benefited this work. We thank John Holloway, Thomas Hanisco, Glenn Wolfe, and Frank Keutsch for providing $\mathrm{CO}$ and $\mathrm{HCHO}$ measurements during SENEX, as well as Ron Cohen, Bill Brune, David Tan, and Brian Heikes for providing $\mathrm{NO}, \mathrm{NO}_{2}$, and $\mathrm{CH}_{3} \mathrm{OOH}$ measurements during INTEX-A and INTEX-B. SOAS measurements used here were performed at the Centreville, AL, SEARCH site, which is funded by Southern Company and EPRI. We thank Bob Yantosca for his work developing compatibility for GEOS-FP within GEOS-Chem. We also thank Jay Turner as well as Dhruv Mitroo and the rest of the ACT Lab at WUStL for their help during the SLAQRS deployment. BJW acknowledges the US EPA Science to Achieve Results (STAR) program (grant \#R835402) for support during SLAQRS. HCHO measurements during SENEX were also supported by EPA STAR (grant \#83540601). This research 
has not been subjected to any EPA review and therefore does not necessarily reflect the views of the Agency, and no official endorsement should be inferred.

Edited by: J. Williams

\section{References}

Alam, M. S., Camredon, M., Rickard, A. R., Carr, T., Wyche, K. P., Hornsby, K. E., Monks, P. S., and Bloss, W. J.: Total radical yields from tropospheric ethene ozonolysis, Phys. Chem. Chem. Phys., 13, 11002-11015, 2011.

Amos, H. M., Jacob, D. J., Holmes, C. D., Fisher, J. A., Wang, Q., Yantosca, R. M., Corbitt, E. S., Galarneau, E., Rutter, A. P., Gustin, M. S., Steffen, A., Schauer, J. J., Graydon, J. A., Louis, V. L. St., Talbot, R. W., Edgerton, E. S., Zhang, Y., and Sunderland, E. M.: Gas-particle partitioning of atmospheric $\mathrm{Hg}(\mathrm{II})$ and its effect on global mercury deposition, Atmos. Chem. Phys., 12, 591-603, doi:10.5194/acp-12-591-2012, 2012.

Andreae, M. O., Talbot, R. W., Andreae, T. W., and Harriss, R. C.: Formic and acetic acid over the central Amazon region, Brazil: 1. Dry season, J. Geophys. Res., 93, 1616-1624, 1988.

Andrews, D. U., Heazlewood, B. R., Maccarone, A. T., Conroy, T., Payne, R. J., Jordan, M. J. T., and Kable, S. H.: Phototautomerization of acetaldehyde to vinyl alcohol: A potential route to tropospheric acids, Science, 337, 1203-1206, 2012.

Archibald, A. T., McGillen, M. R., Taatjes, C. A., Percival, C. J., and Shallcross, D. E.: Atmospheric transformation of enols: A potential secondary source of carboxylic acids in the urban troposphere, Geophys. Res. Lett., 34, L21801, doi:10.1029/2007GL031032, 2007.

Archibald, A. T., Petit, A. S., Percival, C. J., Harvey, J. N., and Shallcross, D. E.: On the importance of the reaction between $\mathrm{OH}$ and $\mathrm{RO}_{2}$ radicals, Atmos. Sci. Lett., 10, 102-108, 2009.

Atkinson, D. B. and Spillman, J. L.: Alkyl peroxy radical kinetics measured using near-infrared $\mathrm{CW}$-cavity ring-down spectroscopy, J. Phys. Chem. A, 106, 8891-8902, 2002.

Atkinson, R., Baulch, D. L., Cox, R. A., Crowley, J. N., Hampson, R. F., Hynes, R. G., Jenkin, M. E., Rossi, M. J., Troe, J., and IUPAC Subcommittee: Evaluated kinetic and photochemical data for atmospheric chemistry: Volume II - gas phase reactions of organic species, Atmos. Chem. Phys., 6, 3625-4055, doi:10.5194/acp-6-3625-2006, 2006.

Baasandorj, M., Millet, D. B., Hu, L., Mitroo, D., and Williams, B. J.: Measuring acetic and formic acid by proton-transferreaction mass spectrometry: sensitivity, humidity dependence, and quantifying interferences, Atmos. Meas. Tech., 8, 13031321, doi:10.5194/amt-8-1303-2015, 2015.

Bannan, T. J., Bacak, A., Muller, J. B. A., Booth, A. M., Jones, B., Breton, M. L., Leather, K. E., Ghalaieny, M., Xiao, P., Shallcross, D. E., and Percival, C. J.: Importance of direct anthropogenic emissions of formic acid measured by a chemical ionisation mass spectrometer (CIMS) during the Winter ClearfLo Campaign in London, January 2012, Atmos. Environ., 83, 301-310, 2014.

Bohn, B., Siese, M., and Zetzschn, C.: Kinetics of the $\mathrm{OH}+\mathrm{C}_{2} \mathrm{H}_{2}$ reaction in the presence of $\mathrm{O}_{2}$, J. Chem. Soc., Faraday Trans., 92, 1459-1466, 1996.
Bossolasco, A., Faragó, E. P., Schoemaecker, C., and Fittschen, C.: Rate constant of the reaction between $\mathrm{CH}_{3} \mathrm{O}_{2}$ and $\mathrm{OH}$ radicals, Chem. Phys. Lett., 593, 7-13, 2014.

Brophy, P. and Farmer, D. K.: A switchable reagent ion high resolution time-of-flight chemical ionization mass spectrometer for real-time measurement of gas phase oxidized species: characterization from the 2013 Southern Oxidant and Aerosol Study, Atmos. Meas. Tech. Discuss., 8, 3199-3244, doi:10.5194/amtd8-3199-2015, 2015.

Buras, Z. J., Elsamra, R. M. I., and Green, W. H.: Direct determination of the simplest Criegee intermediate $\left(\mathrm{CH}_{2} \mathrm{OO}\right)$ self reaction rate, J. Phys. Chem. Lett., 5, 2224-2228, 2014.

Butkovskaya, N. I., Pouvesle, N., Kukui, A., Mu, Y., and Le Bras, G.: Mechanism of the $\mathrm{OH}$-initiated oxidation of hydroxyacetone over the temperature range 236-298 K, J. Phys. Chem. A, 110, 6833-6843, 2006a.

Butkovskaya, N. I., Pouvesle, N., Kukui, A., and Le Bras, G.: Mechanism of the $\mathrm{OH}$-initiated oxidation of glycoaldehyde over the temperature range 233-296 K, J. Phys. Chem. A, 110, 13492 13499, 2006b.

Cady-Pereira, K. E., Chaliyakunnel, S., Shephard, M. W., Millet, D. B., Luo, M., and Wells, K. C.: HCOOH measurements from space: TES retrieval algorithm and observed global distribution, Atmos. Meas. Tech., 7, 2297-2311, doi:10.5194/amt-72297-2014, 2014.

Carslaw, D. C. and Ropkins, K.: openair - An R package for air quality data analysis, Environ. Modell. Softw., 27-28, 52-61, doi:10.1016/j.envsoft.2011.09.008, 2012.

Cazorla, M., Wolfe, G. M., Bailey, S. A., Swanson, A. K., Arkinson, H. L., and Hanisco, T. F.: A new airborne laser-induced fluorescence instrument for in situ detection of formaldehyde throughout the troposphere and lower stratosphere, Atmos. Meas. Tech., 8, 541-552, doi:10.5194/amt-8-541-2015, 2015.

Chao, W., Hsieh, J.-T., Chang, C.-H., and Lin, J. J.-M.: Direct kinetic measurement of the reaction of the simplest Criegee intermediate with water vapor, Science, 347, 751-754, 2015.

Chebbi, A. and Carlier, P.: Carboxylic acids in the troposphere, occurrence, sources, and sinks: A review, Atmos. Environ., 30, 4233-4249, 1996.

Chhantyal-Pun, R., Davey, A., Shallcross, D. E., Percival, C. J., and Orr-Ewing, A. J.: A kinetic study of the $\mathrm{CH}_{2} \mathrm{OO}$ Criegee Intermediate self-reaction, reaction with $\mathrm{SO}_{2}$ and unimolecular reaction using cavity ring-down spectroscopy, Phys. Chem. Chem. Phys., 17, 3617-3626, 2015.

Clubb, A. E., Jordan, M. J. T., Kable, S. H., and Osborn, D. L.: Phototautomerization of acetaldehyde to vinyl alcohol: A primary process in UV-irradiated acetaldehyde from 295 to $335 \mathrm{~nm}$, J. Phys. Chem. Lett., 3, 3522-3526, 2012.

Crounse, J. D., Paulot, F., Kjaergaard, H. G., and Wennberg, P. O.: Peroxy radical isomerization in the oxidation of isoprene, Phys. Chem. Chem. Phys., 13, 13607-13613, 2011.

Crounse, J. D., Knap, H. C., Ornso, K. B., Jorgensen, S., Paulot, F., Kjaergaard, H. G., and Wennberg, P. O.: Atmospheric fate of methacrolein. 1. Peroxy radical isomerization following addition of $\mathrm{OH}$ and $\mathrm{O}_{2}$, J. Phys. Chem. A, 116, 5756-5762, 2012.

Daële, V. and Poulet, G.: Kinetics and products of the reactions of $\mathrm{CH}_{3} \mathrm{O}_{2}$ with $\mathrm{Cl}$ and $\mathrm{ClO}$, J. Chim. Phys. PCB, 93, 1081-1099, 1996. 
da Silva, G.: Carboxylic acid catalyzed keto-enol tautomerizations in the gas phase, Angew. Chem. Int. Ed., 49, 7523-7525, 2010.

de Gouw, J. A., Howard, C. J., Custer, T. G., and Fall, R.: Emissions of volatile organic compounds from cut grass and clover are enhanced during the drying process, Geophys. Res. Lett., 26, 811-814, 1999.

de Gouw, J. A. and Warneke, C.: Measurements of volatile organic compounds in the Earth's atmosphere using proton-transferreaction mass spectrometry, Mass Spectrom. Rev., 26, 223-257, 2007

de Gouw, J. A., Middlebrook, A., Brock, C., Gilman, J., Graus, M., Holloway, J., Lerner, B., Liao, J., Trainer, M., Warneke, C., and Welti, A.: Formation of organic aerosol in the outflow from urban areas in the southeastern United States, Goldschmidt Abstracts, 520, 2014

DiGangi, J. P., Boyle, E. S., Karl, T., Harley, P., Turnipseed, A., Kim, S., Cantrell, C., Maudlin III, R. L., Zheng, W., Flocke, F., Hall, S. R., Ullmann, K., Nakashima, Y., Paul, J. B., Wolfe, G. M., Desai, A. R., Kajii, Y., Guenther, A., and Keutsch, F. N.: First direct measurements of formaldehyde flux via eddy covariance: implications for missing in-canopy formaldehyde sources, Atmos. Chem. Phys., 11, 10565-10578, doi:10.5194/acp-1110565-2011, 2011.

Duncan, B. N., Logan, J. A., Bey, I., Megretskaia, I. A., Yantosca, R. M., Novelli, P. C., Jones, N. B., and Rinsland, C. P.: Global budget of CO, 1988-1997: Source estimates and validation with a global model, J. Geophys. Res., 112, D22301, doi:10.1029/2007JD008459, 2007.

Eliason, T. L., Aloisio, S., Donaldson, D. J., Cziczo, D. J., and Vaida, V.: Processing of unsaturated organic acid films and aerosols by ozone, Atmos. Environ., 37, 2207-2219, 2003.

Faragó, E. P., Viskolcz, B., Schoemaecker, C., and Fittschen, C.: Absorption spectrum and absolute absorption cross sections of $\mathrm{CH}_{3} \mathrm{O}_{2}$ radicals and $\mathrm{CH}_{3} \mathrm{I}$ molecules in the wavelength range 7473-7497 cm ${ }^{-1}$, J. Phys. Chem. A, 117, 12802-12811, 2013.

Fischer, E. V., Jacob, D. J., Millet, D. B., Yantosca, R. M., and Mao, J.: The role of the ocean in the global atmospheric budget of acetone, Geophys. Res. Lett., 39, L01807, doi:10.1029/2011GL050086, 2012.

Fittschen, C., Whalley, L. K., and Heard, D. E.: The reaction of $\mathrm{CH}_{3} \mathrm{O}_{2}$ radicals with $\mathrm{OH}$ radicals: A neglected sink for $\mathrm{CH}_{3} \mathrm{O}_{2}$ in the remote atmosphere, Environ. Sci. Technol., 48, 77007701, 2014.

Galloway, J. N., Likens, G. E., Keene, W. C., and Miller, J. M.: The composition of precipitation in remote areas of the world, J. Geophys. Res., 87, 8771-8786, 1982.

Gilman, J. B., Burkhart, J. F., Lerner, B. M., Williams, E. J., Kuster, W. C., Goldan, P. D., Murphy, P. C., Warneke, C., Fowler, C., Montzka, S. A., Miller, B. R., Miller, L., Oltmans, S. J., Ryerson, T. B., Cooper, O. R., Stohl, A., and de Gouw, J. A.: Ozone variability and halogen oxidation within the Arctic and sub-Arctic springtime boundary layer, Atmos. Chem. Phys., 10, 10223-10236, doi:10.5194/acp-10-10223-2010, 2010.

Glasius, M., Wessel, S., Christensen, C. S., Jacobsen, J. K., Jorgensen, H. E., Klitgaard, K. C., Petersen, L., Rasmussen, J. K., Hansen, T. S., Lohse, C., Boaretto, E., and Heinemeier, J.: Sources to formic acid studied by carbon isotopic analysis and air mass characterization, Atmos. Environ., 34, 2471-2479, 2000.
Glasius, M., Boel, C., Bruun, N., Easa, L. M., Hornung, P., Klausen, H. S., Klitgaard, K. C., Lindeskov, C., Moller, C. K., Nissen, H., Petersen, A. P. F., Kleefeld, S., Boaretto, E., Hansen, T.S., Heinemeier, J., and Lohse, C.: Relative contribution of biogenic and anthropogenic sources to formic and acetic acids in the atmospheric boundary layer, J. Geophys. Res., 106, 7415-7426, 2001.

Goode, J. G., Yokelson, R. J., Ward, D. E., Susott, R. A., Babbitt, R. E., Davies, M. A., and Hao, W. M.: Measurements of excess $\mathrm{O}_{3}, \mathrm{CO}_{2}, \mathrm{CO}, \mathrm{CH}_{4}, \mathrm{C}_{2} \mathrm{H}_{4}, \mathrm{C}_{2} \mathrm{H}_{2}, \mathrm{HCN}, \mathrm{NO}, \mathrm{NH}_{3}$, $\mathrm{HCOOH}, \mathrm{CH}_{3} \mathrm{COOH}, \mathrm{HCHO}$, and $\mathrm{CH}_{3} \mathrm{OH}$ in 1997 Alaskan biomass burning plumes by airborne fourier transform infrared spectroscopy (AFTIR), J. Geophys. Res., 105, 22147-22166, 2000.

Guenther, A., Karl, T., Harley, P., Wiedinmyer, C., Palmer, P. I., and Geron, C.: Estimates of global terrestrial isoprene emissions using MEGAN (Model of Emissions of Gases and Aerosols from Nature), Atmos. Chem. Phys., 6, 3181-3210, doi:10.5194/acp-63181-2006, 2006.

Guenther, A. B., Jiang, X., Heald, C. L., Sakulyanontvittaya, T., Duhl, T., Emmons, L. K., and Wang, X.: The Model of Emissions of Gases and Aerosols from Nature version 2.1 (MEGAN2.1): an extended and updated framework for modeling biogenic emissions, Geosci. Model Dev., 5, 1471-1492, doi:10.5194/gmd-51471-2012, 2012.

Hasson, A. S., Orzechowska, G., and Paulson, S. E.: Production of stabilized Criegee intermediates and peroxides in the gas phase ozonolysis of alkenes: 1. Ethene,trans-2-butene, and 2,3dimethyl-2-butene, J. Geophys. Res., 106, 34131-34142, 2001.

Hatakeyama, S. and Akimoto, H.: Reactions of Criegee intermediates in the gas phase, Res. Chem. Intermed., 20, 503-524, 1994.

Hatakeyama, S., Washida, N., and Akimoto, H.: Rate constants and mechanisms for the reaction of $\mathrm{OH}(\mathrm{OD})$ radicals with acetylene, propyne, and 2-butyne in air at $297 \pm 2 \mathrm{~K}$, J. Phys. Chem., 90, 173-178, 1986.

Hatch, C. D., Gough, R. V., and Tolbert, M. A.: Heterogeneous uptake of the $\mathrm{C} 1$ to $\mathrm{C} 4$ organic acids on a swelling clay mineral, Atmos. Chem. Phys., 7, 4445-4458, doi:10.5194/acp-7-4445-2007, 2007.

Heald, C. L., Ridley, D. A., Kreidenweis, S. M., and Drury, E. E.: Satellite observations cap the atmospheric organic aerosol budget, Geophys. Res. Lett., 37, L24808, doi:10.1029/2010GL045095, 2010.

Holloway, J. S., Jakoubek, R. O., Parrish, D. D., Gerbig, C., VolzThomas, A., Schmitgen, S., Fried, A., Wert, B., Henry, B., and Drummond, J. R.: Airborne intercomparison of vacuum ultraviolet fluorescence and tunable diode laser absorption measurements of tropospheric carbon monoxide, J. Geophys. Res., 105, 24251-24261, 2000.

Hottle, J. R., Huisman, A. J., Digangi, J. P., Kammrath, A., Galloway, M. M., Coens, K. L., and Keutsch, F. N.: A laser induced fluorescence-based instrument for in-situ measurements of atmospheric formaldehyde, Environ. Sci. Technol., 43, 790-795, 2009.

Hu, L., Millet, D. B., Mohr, M. J., Wells, K. C., Griffis, T. J., and Helmig, D.: Sources and seasonality of atmospheric methanol based on tall tower measurements in the US Upper Midwest, Atmos. Chem. Phys., 11, 11145-11156, doi:10.5194/acp-1111145-2011, 2011. 
Hu, L., Millet, D. B., Baasandorj, M., Griffis, T. J., Travis, K. R., Tessum, C. W., Marshall, J. D., Reinhart, W. F., Mikoviny, T., Müller, M., Wisthaler, A., Graus, M., Warneke, C., and de Gouw, J.: Emissions of $\mathrm{C}_{6}-\mathrm{C}_{8}$ aromatic compounds in the United States: Constraints from tall tower and aircraft measurements, J. Geophys. Res., 120, 826-842, doi:10.1002/2014JD022627, 2015a.

Hu, L., Millet, D. B., Baasandorj, M., Griffis, T. J., Turner, P., Helmig, D., Curtis, A. J., and Hueber, J.: Isoprene emissions and impacts over an ecological transition region in the US Upper Midwest inferred from tall tower measurements, J. Geophys. Res., 120, 3553-3571, doi:10.1002/2014JD022732, 2015b.

Jacob, D. J.: Chemistry of $\mathrm{OH}$ in remote clouds and its role in the production of formic acid and peroxymonosulfate, J. Geophys. Res., 91, 9807-9826, 1986.

Jenkin, M. E., Cox, R. A., Emrich, M., and Moortgat, G. K.: Mechanisms of the $\mathrm{Cl}$-atom-initiated oxidation of acetone and hydroxyacetone in air, J. Chem. Soc., Faraday Trans., 89, 2983-2991, 1993.

Jenkin, M. E., Saunders, S. M., and Pilling, M. J.: The tropospheric degradation of volatile organic compounds: A protocol for mechanism development, Atmos. Environ., 31, 81-104, 1997.

Jenkin, M. E., Hurley, M. D., and Wallington, T. J.: Investigation of the radical product channel of the $\mathrm{CH}_{3} \mathrm{COO}_{2}+\mathrm{HO}_{2}$ reaction in the gas phase, Phys. Chem. Chem. Phys., 9, 3149-3162, 2007.

Jordan, C., Fitz, E., Hagan, T., Sive, B., Frinak, E., Haase, K., Cottrell, L., Buckley, S., and Talbot, R.: Long-term study of VOCs measured with PTR-MS at a rural site in New Hampshire with urban influences, Atmos. Chem. Phys., 9, 4677-4697, doi:10.5194/acp-9-4677-2009, 2009.

Jungkamp, T. P. W., Kukui, A., and Schindler, R. N.: Determination of rate constants and product branching ratios for the reactions of $\mathrm{CH}_{3} \mathrm{O}_{2}$ and $\mathrm{CH}_{3} \mathrm{O}$ with $\mathrm{Cl}$ atoms at room temperature, Ber. Bunsen. Phys. Chem., 99, 1057-1066, 1995.

Kaiser, J., Li, X., Tillmann, R., Acir, I., Holland, F., Rohrer, F., Wegener, R., and Keutsch, F. N.: Intercomparison of Hantzsch and fiber-laser-induced-fluorescence formaldehyde measurements, Atmos. Meas. Tech., 7, 1571-1580, doi:10.5194/amt-7-15712014, 2014.

Karton, A.: Inorganic acid-catalyzed tautomerization of vinyl alcohol to acetaldehyde, Chem. Phys. Lett., 592, 330-333, 2014.

Kawamura, K., Ng, L. L., and Kaplan, I. R.: Determination of organic acids (C1-C10) in the atmosphere, motor exhausts, and engine oils, Environ. Sci. Technol., 19, 1082-1086, 1985.

Keene, W. C. and Galloway, J. N.: Organic acidity in precipitation of North America, Atmos. Environ., 18, 2491-2497, 1984.

Keene, W. C., Galloway, J. N., and Holden, J. D.: Measurement of weak organic acidity in precipitation from remote areas of the world, J. Geophys. Res., 88, 5122-5130, 1983.

Kesselmeier, J.: Exchange of short-chain oxygenated volatile organic compounds (VOCs) between plants and the atmosphere: A compilation of field and laboratory studies, J. Atmos. Chem., 39, 219-233, 2001.

Kesselmeier, J. and Staudt, M.: Biogenic volatile organic compounds (VOC): An overview on emission, physiology and ecology, J. Atmos. Chem., 33, 23-88, 1999.

Kesselmeier, J., Bode, K., Gerlach, C., and Jork, E. M.: Exchange of atmospheric formic and acetic acids with trees and crop plants under controlled chamber and purified air conditions, Atmos. Environ., 32, 1765-1775, 1998.
Kim, S. Y., Millet, D. B., Hu, L., Mohr, M. J., Griffis, T. J., Wen, D., Lin, J. C., Miller, S. M., and Longo, M.: Constraints on carbon monoxide emissions based on tall tower measurements in the U.S. Upper Midwest, Environ. Sci. Technol., 47, 8316-8324, 2013.

Kirstine, W., Galbally, I., Ye, Y. R., and Hooper, M.: Emissions of volatile organic compounds (primarily oxygenated species) from pasture, J. Geophys. Res., 103, 10605-10619, 1998.

Kuhn, U., Rottenberger, S., Biesenthal, T., Ammann, C., Wolf, A., Schebeske, G., Oliva, S. T., Tavares, T. M., and Kesselmeier, J.: Exchange of short-chain monocarboxylic acids by vegetation at a remote tropical forest site in Amazonia, J. Geophys. Res., 107, 8069, doi:10.1029/2000JD000303, 2002.

Larsen, B. R., Di Bella, D., Glasius, M., Winterhalter, R., Jensen, N. R., and Hjorth, J.: Gas-phase $\mathrm{OH}$ oxidation of monoterpenes: Gaseous and particulate products, J. Atmos. Chem., 38, 231-276, 2001.

Le Breton, M., McGillen, M. R., Muller, J. B. A., Bacak, A., Shallcross, D. E., Xiao, P., Huey, L. G., Tanner, D., Coe, H., and Percival, C. J.: Airborne observations of formic acid using a chemical ionization mass spectrometer, Atmos. Meas. Tech., 5, 30293039, doi:10.5194/amt-5-3029-2012, 2012.

Lee, A., Goldstein, A. H., Keywood, M. D., Gao, S., Varutbangkul, V., Bahreini, R., Ng, N. L., Flagan, R. C., and Seinfeld, J. H.: Gas-phase products and secondary aerosol yields from the ozonolysis of ten different terpenes, J. Geophys. Res., 111, D07302, doi:10.1029/2005JD006437, 2006a.

Lee, A., Goldstein, A. H., Kroll, J. H., Ng, N. L., Varutbangkul, V., Flagan, R. C., and Seinfeld, J. H.: Gas-phase products and secondary aerosol yields from the photooxidation of 16 different terpenes, J. Geophys. Res., 111, D17305, doi:10.1029/2006JD007050, 2006b.

Lee, B. H., Lopez-Hilfiker, F. D., Mohr, C., Kurtén, T., Worsnop, D. R., and Thornton, J. A.: An iodide-adduct high-resolution time-of-flight chemical-ionization mass spectrometer: Application to atmospheric inorganic and organic compounds, Environ. Sci. Technol., 48, 6309-6317, 2014.

Lee, J. H., Leahy, D. F., Tang, I. N., and Newman, L.: Measurement and speciation of gas phase peroxides in the atmosphere, $\mathrm{J}$ Geophys. Res., 98, 2911-2915, 1993.

Lee, M., Noone, B. C., O'Sullivan, D., and Heikes, B. G.: Method for the collection and HPLC analysis of hydrogen peroxide and $\mathrm{C}_{1}$ and $\mathrm{C}_{2}$ hydroperoxides in the atmosphere, J. Atmos. Oceanic Technol., 12, 1060-1070, 1995.

Lelieveld, J. and Crutzen, P. J.: The role of clouds in tropospheric chemistry, J. Atmos. Chem., 12, 229-267, 1991.

Lin, J.-T. and McElroy, M.: Impacts of boundary layer mixing on pollutant vertical profiles in the lower troposphere: Implications to satellite remote sensing, Atmos. Environ., 44, 1726-1739, doi:10.1016/j.atmosenv.2010.02.009, 2010.

Lin, S.-J. and Rood, R. B.: Multidimensional flux form semiLagrangian transport schemes, Mon. Weather Rev., 124, 20462070, 1996.

Liu, J., Zhang, X., Parker, E. T., Veres, P. R., Roberts, J. M., Gouw, J. A. D., Hayes, P. L., Jimenez, J. L., Murphy, J. G., Ellis, R. A., Huey, L. G., and Weber, R. J.: On the gas-particle partitioning of soluble organic aerosol in two urban atmospheres with contrasting emissions: 2. Gas and particle phase formic acid, J. Geophys Res., 117, D00V21, doi:10.1029/2012JD017912, 2012. 
Liu, Y. J., Herdlinger-Blatt, I., McKinney, K. A., and Martin, S. T.: Production of methyl vinyl ketone and methacrolein via the hydroperoxyl pathway of isoprene oxidation, Atmos. Chem. Phys., 13, 5715-5730, doi:10.5194/acp-13-5715-2013, 2013.

Mao, J., Jacob, D. J., Evans, M. J., Olson, J. R., Ren, X., Brune, W. H., St. Clair, J. M., Crounse, J. D., Spencer, K. M., Beaver, M. R., Wennberg, P. O., Cubison, M. J., Jimenez, J. L., Fried, A., Weibring, P., Walega, J. G., Hall, S. R., Weinheimer, A. J., Cohen, R. C., Chen, G., Crawford, J. H., McNaughton, C., Clarke, A. D., Jaeglé, L., Fisher, J. A., Yantosca, R. M., Le Sager, P., and Carouge, $\mathrm{C}$. .: Chemistry of hydrogen oxide radicals $\left(\mathrm{HO}_{\mathrm{X}}\right)$ in the Arctic troposphere in spring, Atmos. Chem. Phys., 10, 58235838, doi:10.5194/acp-10-5823-2010, 2010.

Mao, J., Paulot, F., Jacob, D. J., Cohen, R. C., Crounse, J. D., Wennberg, P. O., Keller, C. A., Hudman, R. C., Barkley, M. P., and Horowitz, L. W.: Ozone and organic nitrates over the eastern United States: Sensitivity to isoprene chemistry, J. Geophys. Res., 118, 11256-11268, doi:10.1002/jgrd.50817, 2013a.

Mao, J., Fan, S., Jacob, D. J., and Travis, K. R.: Radical loss in the atmosphere from $\mathrm{Cu}-\mathrm{Fe}$ redox coupling in aerosols, Atmos. Chem. Phys., 13, 509-519, doi:10.5194/acp-13-509-2013, 2013b.

Maricq, M. M., Szente, J. J., Kaiser, E. W., and Shi, J.: Reaction of chlorine atoms with methylperoxy and ethylperoxy radicals, J. Phys. Chem., 98, 2083-2089, 1994.

McKinney, K. A., Lee, B. H., Vasta, A., Pho, T. V., and Munger, J. W.: Emissions of isoprenoids and oxygenated biogenic volatile organic compounds from a New England mixed forest, Atmos. Chem. Phys., 11, 4807-4831, doi:10.5194/acp-11-4807-2011, 2011.

Millet, D. B., Jacob, D. J., Boersma, K. F., Fu, T. M., Kurosu, T. P., Chance, K., Heald, C. L., and Guenther, A.: Spatial distribution of isoprene emissions from North America derived from formaldehyde column measurements by the OMI satellite sensor, J. Geophys. Res., 113, D02307, doi:10.1029/2007JD008950, 2008a.

Millet, D. B., Jacob, D. J., Custer, T. G., de Gouw, J. A., Goldstein, A. H., Karl, T., Singh, H. B., Sive, B. C., Talbot, R. W., Warneke, C., and Williams, J.: New constraints on terrestrial and oceanic sources of atmospheric methanol, Atmos. Chem. Phys., 8, 68876905, doi:10.5194/acp-8-6887-2008, 2008b.

Millet, D. B., Guenther, A., Siegel, D. A., Nelson, N. B., Singh, H. B., de Gouw, J. A., Warneke, C., Williams, J., Eerdekens, G., Sinha, V., Karl, T., Flocke, F., Apel, E., Riemer, D. D., Palmer, P. I., and Barkley, M.: Global atmospheric budget of acetaldehyde: 3-D model analysis and constraints from in-situ and satellite observations, Atmos. Chem. Phys., 10, 3405-3425, doi:10.5194/acp-10-3405-2010, 2010.

Molina, M. J., Ivanov, A. V., Trakhtenberg, S., and Molina, L. T.: Atmospheric evolution of organic aerosol, Geophys. Res. Lett., 31, L22104, doi:10.1029/2004GL020910, 2004.

Myneni, R. B., Yang, W., Nemani, R. R., Huete, A. R., Dickinson, R. E., Knyazikhin, Y., Didan, K., Fu, R., Negron Juarez, R. I., Saatchi, S. S., Hashimoto, H., Ichii, K., Shabanov, N. V., Tan, B., Ratana, P., Privette, J. L., Morisette, J. T., Vermote, E. F., Roy, D. P., Wolfe, R. E., Friedl, M. A., Running, S. W., Votava, P., ElSaleous, N., Devadiga, S., Su, Y., and Salomonson, V. V.: Large seasonal swings in leaf area of Amazon rainforests, P. Natl. Acad. Sci. USA, 104, 4820-4823, 2007.
Neeb, P., Horie, O., and Moortgat, G. K.: Gas-phase ozonolysis of ethene in the presence of hydroxylic compounds, Int. J. Chem. Kinet., 28, 721-730, 1996.

Neeb, P., Sauer, F., Horie, O., and Moortgat, G. K.: Formation of hydroxymethyl hydroperoxide and formic acid in alkene ozonolysis in the presence of water vapour, Atmos. Environ., 31, 14171423, 1997.

Neuman, J. A., Huey, L. G., Dissly, R. W., Fehsenfeld, F. C., Flocke, F., Holecek, J. C., Holloway, J. S., Hübler, G., Jakoubek, R., Nicks Jr., D. K., Parrish, D. D., Ryerson, T. B., Sueper, D. T., and Weinheimer, J.: Fast-response airborne in situ measurements of $\mathrm{HNO}_{3}$ during the Texas 2000 Air Quality Study, J. Geophys. Res., 107, 4436, doi:10.1029/2001JD001437, 2002.

Neuman, J. A., Nowak, J. B., Huey, L. G., Burkholder, J. B., Dibb, J. E., Holloway, J. S., Liao, J., Peischl, J., Roberts, J. M., Ryerson, T. B., Scheuer, E., Stark, H., Stickel, R. E., Tanner, D. J., and Weinheimer, A.: Bromine measurements in ozone depleted air over the Arctic Ocean, Atmos. Chem. Phys., 10, 6503-6514, doi:10.5194/acp-10-6503-2010, 2010.

Newland, M. J., Rickard, A. R., Alam, M. S., Vereecken, L., Muñoz, A., Ródenas, M., and Bloss, W. J.: Kinetics of stabilised Criegee intermediates derived from alkene ozonolysis: reactions with $\mathrm{SO}_{2}, \mathrm{H}_{2} \mathrm{O}$ and decomposition under boundary layer conditions, Phys. Chem. Chem. Phys., 17, 4076-4088, 2015.

Ngwabie, N. M., Schade, G. W., Custer, T. G., Linke, S., and Hinz, T.: Abundances and flux estimates of volatile organic compounds from a dairy cowshed in Germany, J. Environ. Qual., 37, 565$573,2008$.

Oleson, K. W., Lawrence, D. M., Bonan, G. B., Flanner, M. G., Kluzek, E., Lawrence, P. J., Levis, S., Swenson, S. C., Thornton, P. E., Dai, A., Decker, M., Dickinson, R., Feddema, J., Heald, C. L., Hoffman, F., Lamarque, J., Mahowald, N., Niu, G., Qian, T., Randerson, J., Running, S., Sakaguchi, K., Slater, A., Stockli, R., Wang, A., Yang, Z., Zeng, X., and Zeng, X.: Technical Description of version 4.0 of the Community Land Model (CLM), National Center for Atmospheric Research, Technical Note NCAR/TN-478+STR, doi:10.5065/D6FB50WZ, Boulder, CO, 2010.

Olivier, J. G. J., van Aardenne, J. A., Dentener, F. J., Pagliari, V., Ganzeveld, L. N., and Peters, J. A. H. W.: Recent trends in global greenhouse gas emissions: Regional trends 1970-2000 and spatial distribution of key sources in 2000, Environ. Sci., 2, 81-99, doi:10.1080/15693430500400345, 2005.

Orlando, J. J., Nozière, B., Tyndall, G. S., Orzechowska, G. E., Paulson, S. E., and Rudich, Y.: Product studies of the $\mathrm{OH}-$ and ozone-initiated oxidation of some monoterpenes, J. Geophys. Res., 105, 11561-11572, 2000.

Orlando, J. J., Tyndall, G. S., and Taraborrelli, D.:, Atmospheric oxidation of two isoprene by-products, hydroxyacetone and glycoaldehyde, Abstract A33L-0315, in 2012 Fall Meeting, AGU, San Francisco, Calif., 3-7 December, 2012.

Orzechowska, G. E. and Paulson, S. E.: Photochemical sources of organic acids. 1. Reactions of ozone with isoprene, propene, and 2-butenes under dry and humid conditions using SPME, J. Phys. Chem. A, 109, 5358-5365, 2005.

Pan, X., Underwood, J. S., Xing, J.-H., Mang, S. A., and Nizkorodov, S. A.: Photodegradation of secondary organic aerosol generated from limonene oxidation by ozone studied with chemi- 
cal ionization mass spectrometry, Atmos. Chem. Phys., 9, 38513865, doi:10.5194/acp-9-3851-2009, 2009.

Park, J., Gomez, A. L., Walser, M. L., Lin, A., and Nizkorodov, S. A.: Ozonolysis and photolysis of alkene-terminated selfassembled monolayers on quartz nanoparticles: implications for photochemical aging of organic aerosol particles, Phys. Chem. Chem. Phys., 8, 2506-2512, 2006.

Paulot, F., Crounse, J. D., Kjaergaard, H. G., Kroll, J. H., Seinfeld, J. H., and Wennberg, P. O.: Isoprene photooxidation: new insights into the production of acids and organic nitrates, Atmos. Chem. Phys., 9, 1479-1501, doi:10.5194/acp-9-1479-2009, 2009a.

Paulot, F., Crounse, J. D., Kjaergaard, H. G., Kurten, A., St Clair, J. M., Seinfeld, J. H., and Wennberg, P. O.: Unexpected epoxide formation in the gas-phase photooxidation of isoprene, Science, 325, 730-733, 2009b.

Paulot, F., Wunch, D., Crounse, J. D., Toon, G. C., Millet, D. B., DeCarlo, P. F., Vigouroux, C., Deutscher, N. M., González Abad, G., Notholt, J., Warneke, T., Hannigan, J. W., Warneke, C., de Gouw, J. A., Dunlea, E. J., De Mazière, M., Griffith, D. W. T., Bernath, P., Jimenez, J. L., and Wennberg, P. O.: Importance of secondary sources in the atmospheric budgets of formic and acetic acids, Atmos. Chem. Phys., 11, 1989-2013, doi:10.5194/acp-11-1989-2011, 2011.

Pollack, I. B., Lerner, B. M., and Ryerson, T. B.: Evaluation of ultraviolet light-emitting diodes for detection of atmospheric $\mathrm{NO}_{2}$ by photolysis - chemiluminescence, J. Atmos. Chem., 65, 111-125, 2010.

Pushkarsky, M. B., Zalyubovsky, S. J., and Miller, T. A.: Detection and characterization of alkyl peroxy radicals using cavity ringdown spectroscopy, J. Chem. Phys., 112, 10695-10698, 2000.

R'Honi, Y., Clarisse, L., Clerbaux, C., Hurtmans, D., Duflot, V., Turquety, S., Ngadi, Y., and Coheur, P.-F.: Exceptional emissions of $\mathrm{NH}_{3}$ and $\mathrm{HCOOH}$ in the 2010 Russian wildfires, Atmos. Chem. Phys., 13, 4171-4181, doi:10.5194/acp-13-41712013, 2013.

Ryerson, T. B., Williams, E. J., and Fehsenfeld, F. C.: An efficient photolysis system for fast-response $\mathrm{NO}_{2}$ measurements, J. Geophys. Res., 105, 26447-26461, 2000.

Ryzhkov, A. B. and Ariya, P. A.: A theoretical study of the reactions of carbonyl oxide with water in atmosphere: The role of water dimer, Chem. Phys. Lett., 367, 423-429, 2003.

Sander, R.: Compilation of Henry's law constants (version 4.0) for water as solvent, Atmos. Chem. Phys., 15, 4399-4981, doi:10.5194/acp-15-4399-2015, 2015.

Sanhueza, E. and Andreae, M. O.: Emission of formic and acetic acids from tropical savanna soils, Geophys. Res. Lett., 18, 17071710, 1991.

Sauer, F., Beck, J., Schuster, G., and Moortgat, G. K.: Hydrogen peroxide, organic peroxides and organic acids in a forested area during FIELDVOC'94, Chemosphere, 3, 309-326, 2001.

Saunders, S. M., Jenkin, M. E., Derwent, R. G., and Pilling, M. J.: Protocol for the development of the Master Chemical Mechanism, MCM v3 (Part A): tropospheric degradation of nonaromatic volatile organic compounds, Atmos. Chem. Phys., 3, 161-180, doi:10.5194/acp-3-161-2003, 2003.

Schultz, M. G., Backman, L., Balkanski, Y., Bjoerndalsaeter, S., Brand, R., Burrows, J. P., Dalsoeren, S., Vasconcelos, M. D., Grodtmann, B., Hauglustaine, D. A., Heil, A., Hoelzemann, J. J., Isaksen, I. S. A., Kaurola, J., Knorr, W., Ladstaetter-
Weißenmayer, A., Mota, B., Oom, D., Pacyna, J., Panasiuk, D., Pereira, J. M. C., Pulles, T., Pyle, J., Rast, S., Richter, A., Savage, N., Schnadt, C., Schulz, M., Spessa, A., Staehelin, J., Sundet, J. K., Szopa, S., Thonicke, K., van het Bolscher, M., Noije, T. V., Velthoven, P. V., Vik, A. F., and Wittrock, F.: REanalysis of the TROpospheric chemical composition over the past 40 years - A long-term global modeling study of tropospheric chemistry, available at: http://retro.enes.org/ (last access: 1 January 2012), 5th EU framework programme, Jülich/Hamburg, Germany, 2007.

Shallcross, D. E., Leather, K. E., Bacak, A., Xiao, P., Lee, E. P. F., Ng, M., Mok, D. K. W., Dyke, J. M., Hossaini, R., Chipperfield, M. P., Khan, M. A. H., and Percival, C. J.: Reaction between $\mathrm{CH}_{3} \mathrm{O}_{2}$ and $\mathrm{BrO}$ radicals: A new source of upper troposphere lower stratosphere hydroxyl radicals, J. Phys. Chem. A, 119, 4618-4632, doi:10.1021/jp5108203, 2015.

Singh, H. B., Brune, W. H., Crawford, J. H., Jacob, D. J., and Russell, P. B.: Overview of the summer 2004 intercontinental chemical transport experiment - North America (INTEX-A), J. Geophys. Res., 111, D24S01, doi:10.1029/2006JD007905, 2006.

Singh, H. B., Brune, W. H., Crawford, J. H., Flocke, F., and Jacob, D. J.: Chemistry and transport of pollution over the Gulf of Mexico and the Pacific: spring 2006 INTEX-B campaign overview and first results, Atmos. Chem. Phys., 9, 2301-2318, doi:10.5194/acp-9-2301-2009, 2009.

So, S., Wille, U., and da Silva, G.: Atmospheric chemistry of enols: A theoretical study of the vinyl alcohol $+\mathrm{OH}+\mathrm{O}_{2}$ reaction mechanism, Environ. Sci. Technol., 48, 6694-6701, 2014.

Stavrakou, T., Guenther, A., Razavi, A., Clarisse, L., Clerbaux, C., Coheur, P.-F., Hurtmans, D., Karagulian, F., De Mazière, M., Vigouroux, C., Amelynck, C., Schoon, N., Laffineur, Q., Heinesch, B., Aubinet, M., Rinsland, C., and Müller, J.-F.: First space-based derivation of the global atmospheric methanol emission fluxes, Atmos. Chem. Phys., 11, 4873-4898, doi:10.5194/acp-11-4873-2011, 2011.

Stavrakou, T., Müller, J.-F., Peeters, J., Razavi, A., Clarisse, L., Clerbaux, C., Coheur, P.-F., Hurtmans, D., Mazière, M. D., Vigouroux, C., Deutscher, N. M., Griffith, D. W. T., Jones, N., and Paton-Walsh, C.: Satellite evidence for a large source of formic acid from boreal and tropical forests, Nat. Geosci., 5, 2630, 2012.

Stone, D., Blitz, M., Daubney, L., Howes, N. U., and Seakins, P.: Kinetics of $\mathrm{CH}_{2} \mathrm{OO}$ reactions with $\mathrm{SO}_{2}, \mathrm{NO}_{2}, \mathrm{NO}, \mathrm{H}_{2} \mathrm{O}$ and $\mathrm{CH}_{3} \mathrm{CHO}$ as a function of pressure, Phys. Chem. Chem. Phys., 16, 1139-1149, 2014.

Su, Y.-T., Lin, H.-Y., Putikam, R., Matsui, H., Lin, M. C., and Lee, Y.-P.: Extremely rapid self-reaction of the simplest Criegee intermediate $\mathrm{CH}_{2} \mathrm{OO}$ and its implications in atmospheric chemistry, Nature Chem., 6, 477-483, 2014.

Taatjes, C. A., Meloni, G., Selby, T. M., Trevitt, A. J., Osborn, D. L., Percival, C. J., and Shallcross, D. E.: Direct observation of the gas-phase Criegee intermediate $\left(\mathrm{CH}_{2} \mathrm{OO}\right)$, J. Am. Chem. Soc., 130, 11883-11885, 2008.

Talbot, R. W., Beecher, K. M., Harriss, R. C., and Cofer, W. R.: Atmospheric geochemistry of formic and acetic acids at a midlatitude temperate site, J. Geophys. Res., 93, 1638-1652, 1988.

Ting, W. L., Chang, C. H., Lee, Y. F., Matsui, H., Lee, Y. P., and Lin, J. J.: Detailed mechanism of the $\mathrm{CH}_{2} \mathrm{I}+\mathrm{O}_{2}$ reaction: Yield and self-reaction of the simplest Criegee intermediate $\mathrm{CH}_{2} \mathrm{OO}$, J. Chem. Phys., 141, 104308, doi:10.1063/1.4894405, 2014. 
Valverde-Canossa, J., Ganzeveld, L., Rappenglück, B., Steinbrecher, R., Klemm, O., Schuster, G., and Moortgat, G. K.: First measurements of $\mathrm{H}_{2} \mathrm{O}_{2}$ and organic peroxides surface fluxes by the relaxed eddy-accumulation technique, Atmos. Environ., 40, S55-S67, 2006.

van der Werf, G. R., Randerson, J. T., Giglio, L., Collatz, G. J., Mu, M., Kasibhatla, P. S., Morton, D. C., DeFries, R. S., Jin, Y., and van Leeuwen, T. T.: Global fire emissions and the contribution of deforestation, savanna, forest, agricultural, and peat fires (19972009), Atmos. Chem. Phys., 10, 11707-11735, doi:10.5194/acp10-11707-2010, 2010.

Vereecken, L., Harder, H., and Novelli, A.: The reaction of Criegee intermediates with $\mathrm{NO}, \mathrm{RO}_{2}$, and $\mathrm{SO}_{2}$, and their fate in the atmosphere, Phys. Chem. Chem. Phys., 14, 14682-14695, 2012.

Veres, P. R., Roberts, J. M., Cochran, A. K., Gilman, J. B., Kuster, W. C., Holloway, J. S., Graus, M., Flynn, J., Lefer, B., Warneke, C., and de Gouw, J.: Evidence of rapid production of organic acids in an urban air mass, Geophys. Res. Lett., 38, L17807, doi:10.1029/2011GL048420, 2011.

Vlasenko, A., George, I. J., and Abbatt, J. P. D.: Formation of volatile organic compounds in the heterogeneous oxidation of condensed-phase organic films by gas-phase $\mathrm{OH}$, J. Phys. Chem. A, 112, 1552-1560, 2008.

Walser, M. L., Park, J., Gomez, A. L., Russell, A. R., and Nizkorodov, S. A.: Photochemical aging of secondary organic aerosol particles generated from the oxidation of d-limonene, J. Phys. Chem. A, 111, 1907-1913, 2007.

Wang, Y. H., Jacob, D. J., and Logan, J. A.: Global simulation of tropospheric $\mathrm{O}_{3}-\mathrm{NO}_{x}$-hydrocarbon chemistry: 1 . Model formulation, J. Geophys. Res., 103, 10713-10725, 1998.

Weinstein-Lloyd, J. B., Lee, J. H., Daum, P. H., Kleinman, L. I., Nunnermacker, L. J., Springston, S. R., and Newman, L.: Measurements of peroxides and related species during the 1995 summer intensive of the Southern Oxidants Study in Nashville, Tennessee, J. Geophys. Res., 103, 22361-22373, 1998.

Wells, K. C., Millet, D. B., Hu, L., Cady-Pereira, K. E., Xiao, Y., Shephard, M. W., Clerbaux, C. L., Clarisse, L., Coheur, P. F., Apel, E. C., de Gouw, J., Warneke, C., Singh, H. B., Goldstein, A. H., and Sive, B. C.: Tropospheric methanol observations from space: retrieval evaluation and constraints on the seasonality of biogenic emissions, Atmos. Chem. Phys., 12, 5897-5912, doi:10.5194/acp-12-5897-2012, 2012.

Wells, K. C., Millet, D. B., Cady-Pereira, K. E., Shephard, M. W., Henze, D. K., Bousserez, N., Apel, E. C., de Gouw, J., Warneke, C., and Singh, H. B.: Quantifying global terrestrial methanol emissions using observations from the TES satellite sensor, Atmos. Chem. Phys., 14, 2555-2570, doi:10.5194/acp-14-25552014, 2014.
Welz, O., Savee, J. D., Osborn, D. L., Vasu, S. S., Percival, C. J., Shallcross, D. E., and Taatjes, C. A.: Direct kinetic measurements of Criegee Intermediate $\left(\mathrm{CH}_{2} \mathrm{OO}\right)$ formed by reaction of $\mathrm{CH}_{2}$ I with $\mathrm{O}_{2}$, Science, 335, 204-207, 2012.

Welz, O., Eskola, A. J., Sheps, L., Rotavera, B., Savee, J. D., Scheer, A. M., Osborn, D. L., Lowe, D., Murray Booth, A., Xiao, P., Anwar, H. K. M., Percival, C. J., Shallcross, D. E., and Taatjes, C. A.: Rate coefficients of $\mathrm{C} 1$ and $\mathrm{C} 2$ Criegee intermediate reactions with formic and acetic acid near the collision limit: Direct kinetics measurements and atmospheric implications, Angew. Chem. Int. Ed., 53, 4547-4550, 2014.

Wesely, M. L.: Parameterization of surface resistances to gaseous dry deposition in regional-scale numerical models, Atmos. Environ., 23, 1293-1304, 1989.

Wiedinmyer, C., Greenberg, J., Guenther, A., Hopkins, B., Baker, K., Geron, C., Palmer, P. I., Long, B. P., Turner, J. R., Petron, G., Harley, P., Pierce, T. E., Lamb, B., Westberg, H., Baugh, W., Koerber, M., and Janssen, M.: Ozarks Isoprene Experiment (OZIE): Measurements and modeling of the "isoprene volcano", J. Geophys. Res., 110, D18307, doi:10.1029/2005JD005800, 2005.

Wu, S. L., Mickley, L. J., Jacob, D. J., Logan, J. A., Yantosca, R. M., and Rind, D.: Why are there large differences between models in global budgets of tropospheric ozone?, J. Geophys. Res., 112, D05302, doi:10.1029/2006JD007801, 2007.

Yevich, R. and Logan, J.A.: An assessment of biofuel use and burning of agricultural waste in the developing world, Global Biogeochem. Cy., 17, 1095, doi:10.1029/2002GB001952, 2003.

Yuan, B., Veres, P. R., Warneke, C., Roberts, J. M., Gilman, J. B., Koss, A., Edwards, P. M., Graus, M., Kuster, W. C., Li, S.-M., Wild, R. J., Brown, S. S., Dubé, W. P., Lerner, B. M., Williams, E. J., Johnson, J. E., Quinn, P. K., Bates, T. S., Lefer, B., Hayes, P. L., Jimenez, J. L., Weber, R. J., Zamora, R., Ervens, B., Millet, D. B., Rappenglück, B., and de Gouw, J. A.: Investigation of secondary formation of formic acid: urban environment vs. oil and gas producing region, Atmos. Chem. Phys., 15, 1975-1993, doi:10.5194/acp-15-1975-2015, 2015.

Zander, R., Duchatelet, P., Mahieu, E., Demoulin, P., Roland, G., Servais, C., Auwera, J. V., Perrin, A., Rinsland, C. P., and Crutzen, P. J.: Formic acid above the Jungfraujoch during 1985-2007: observed variability, seasonality, but no long-term background evolution, Atmos. Chem. Phys., 10, 10047-10065, doi:10.5194/acp-10-10047-2010, 2010. 